\title{
"A thing of beauty is a joy forever". Plants and plant-based preparations for facial care in Suriname
}

\author{
Dennis RA Mans ${ }^{1 *}$ and Angela Grant ${ }^{2}$ \\ ${ }^{1}$ Department of Pharmacology, Faculty of Medical Sciences, Anton de Kom University of Suriname, Paramaribo, Suriname \\ ${ }^{2}$ National Herbarium of Suriname, Anton de Kom University of Suriname, Paramaribo, Suriname
}

\begin{abstract}
People have probably used plant-based substances to improve their appearance since the existence of mankind. The first documented use of cosmetics dates back to 3,000 BC from ancient Egypt, but it is safe to say that this custom has been (and still is) an integral part of daily life in all civilizations. The initial use of plantderived makeup - sometimes supplemented with paints and dyes - has come full circle and is back with the contemporary trend of using beauty products that are mainly derived from plant sources. The Republic of Suriname (South America) is renowned for its extensive ethnopharmacological knowledge and unique plant biodiversity that provides ample raw material that can be processed into cosmetics and cosmeceuticals. This paper gives some historical highlights on the use of makeup throughout the world with the emphasis on naturally-derived products; focuses on the herbal cosmetics industry in Suriname; extensively addresses the scientific rationale for incorporating extracts from plants in cosmetics and cosmeceuticals in the country; and concludes with the conditions to establish a beauty products industry in Suriname.
\end{abstract}

\section{Introduction}

Since times immemorial humans from all civilizations have used substances from a myriad of sources to increase their beauty, maintain a youthful appearance, heighten their sensuality, and, generally, preserve their health and hygiene [1,2]. Products that are used for these purposes are nowadays commonly known as cosmetics and cosmeceuticals. They are intended for 'the art of beautifying', the Latinized expression of the ancient Greek practices of 'kosmetike' and 'kosmetikos' meaning 'the art of dress and ornament' and 'skilled in ordering or arranging', respectively.

Cosmetics are articles for cleansing, beautifying, promoting the attractiveness, or positively altering the appearance of the body $[1,2]$. These products generally do not contain pharmacologically active ingredients, at least, not at the scientifically proven levels or in a delivery system to benefit the skin [1,2]. They are, furthermore, relatively safe, sold over the counter, and widely available from, among others, supermarkets, drug stores, salons, and on-line retailers. Typical cosmetics are lipsticks, eye shadows, moisturizers, toothpastes, regular shampoos and conditioners, hair dyes, fingernail polishes, and deodorants $[1,2]$.

Cosmeceuticals - also called cosmedics or cosmedicals - are skin care products with bioactive ingredients with medicinal or drug-like benefits in addition to cosmetic features [1,2]. They contain active ingredients at scientifically proven levels that positively affect the skin and are in a delivery system that ensures penetration of the skin by the active ingredients $[1,2]$. These products can elicit structural changes in the skin and beneficial effects in skin conditions such as acne, hyperpigmentation, and ageing [1,2]. However, cosmeceuticals are not considered pharmaceutical products, do not require a medical prescription to dispense, and can regularly be used on the skin without risking major side-effects $[1,2]$. Examples of cosmeceuticals are natural and synthetic derivatives of vitamin $\mathrm{A}$, antioxidants, anti-dandruff shampoos containing an anti-fungal compound, sunscreens with proven sun protection factor, toothpastes supplemented with fluoride, and deodorants that contain antiperspirants $[1,2]$.

\section{Background}

\section{The ancient times}

The discovery of red ochre including crayons from the African Middle Stone Age over 100,000 years ago [3] dates the application of cosmetic body art to the emergence of Homo sapiens in Africa [4]. Additional evidence for the early use of cosmetics comes for archeological finds demonstrating that already around 10,000 BC men and women in ancient Egypt used scented oils and ointments to clean and soften their skin and mask their body odor [5]. From about $3,000 \mathrm{BC}$ on, the use of beauty products and makeup became more widespread in Egypt [6] and expanded to large parts of Africa and Asia [7].

Both men and women applied kohl as eyeliner and eyeshadow which also shielded the eyes from the hot sun and the dry winds [6,7] (Figure 1). People also protected their skin with balms and creams prepared from Castor oil; wore lipsticks containing extracts from red algae, sometimes enriched with a pearlescent substance from fish scales to obtain an iridescent effect; fought wrinkles with the aromatic resin frankincense from trees of the genus Boswellia (Burseraceae) and fresh Moringa olifeira Lam. (Moringaceae); treated baldness and greying hair with a mixture of beeswax and resin; and chewed on licorice sticks from

Correspondence to: Dennis R.A. Mans, Department of Pharmacology, Faculty of Medical Sciences, Anton de Kom University of Suriname. Kernkampweg 5-7, Paramaribo, Suriname. Tel/Fax: +597 441071.E-mail: dennis_mans@yahoo.com

Key words: Suriname, plant-derived products, cosmetics, cosmeceuticals, facial care, scientific rationale

Received: July 17, 2017; Accepted: August 22, 2017; Published: August 25, 2017 


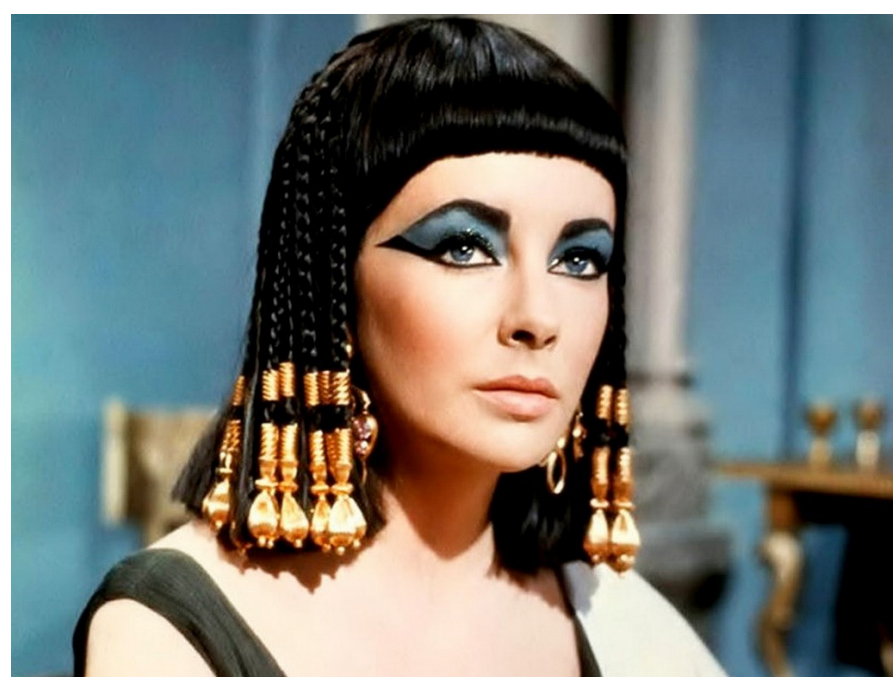

Figure 1. The British-American actress Elizabeth Taylor made up as the Egyptian queen Cleopatra (69 - 30 BC) in the 1963-movie 'Cleopatra' (from https://goo.gl/images/x2IZx8).

the roots of Glycyrrhiza glabra L. (Fabaceae) to improve their breath [5]. Important basic ingredients of most perfumes used in ancient (Egyptian) religious rituals were myrrh, thyme, marjoram, chamomile, lavender, lily, peppermint, rosemary, cedar, rose, aloe, olive oil, sesame oil, and almond oil $[6,7]$.

\section{Ancient Rome}

The tradition of using makeup and beauty products carried on to ancient Rome, where around $100 \mathrm{AD}$ it was incorporated into fashion and religion and became a vital part of everyday life [8]. Slaves bathed the aristocracy in perfume and Roman women daily used perfumes, body oils, skin creams, eye shadows, eye liners, powders, nail products, and teeth-whitening products. They also applied beauty masks to lighten their face as a sign of purity, while Roman men dyed their hair blond. Notably, a woman's social status, wealth, and attractiveness was determined by the makeup she wore and the clothes she was adorned in. In an effort to control lavish and self-indulgent expenditures on luxury and extravagance, the Lex Oppia was established in $215 \mathrm{BC}$ which, among others, restricted the amount of beauty products and luxury services women could purchase and wear [9]. This law was revoked six years later, but the Ancient Romans took cosmetics to new heights and limits which may explain why Italy, specifically Milan, is one of the largest beauty empires of the world to this day.

\section{The Middle Ages and the Renaissance}

Cosmetics found their way to Europe during the Middle Ages and the Renaissance between 1,200 and 1,600 AD, after they were brought in from the Middle East in the wake of the Crusades [10]. Wearing makeup was then considered sinful and immoral and was heavily discouraged by church leaders but, nevertheless, grew in popularity. Particularly skin-whitening became fashionable among the aristocracy, as a paler skin complexion was associated with more leisure time to spend indoors and thus a higher social status [11]. This practice lasted until the twentieth century and made use of a broad variety of procedures ranging from the application of egg white and white powder on the face to self-bleeding and the use of deadly toxic substances such as white lead paint and arsenic [11]. One of the most revered users of white lead was Queen Elizabeth I of England (1533 1603) who created 'the Mask of Youth' [10,11] (Figure 2). Blonde hair also rose in popularity as it was considered angelic, and was achieved by applying black sulphur, alum, and honey on the hair and having the mixture react with the hair in the sun [11].

\section{The nineteenth century}

The use of makeup experienced a decline in Europe in the nineteenth century, particularly after Queen Victoria from England (1819 - 1901) publicly declared it improper and vulgar and only acceptable for actresses and prostitutes [12]. 'Respectable' women wore in general as little makeup as possible which was, moreover, applied as discrete as possible. However, facial whitening was still practiced but was accomplished with zinc oxide powder instead of the deadly mixtures of lead and copper [12]. The use of cosmetics resurfaced at the end of the nineteenth century, but full makeup was still regarded as sinful and beauty products were usually home-made articles with natural tones.

\section{The early twentieth century}

Around 1910, makeup became increasingly more fashionable in Europe (as well as the USA) due to the influence of ballet and theatre stars. Colored makeup was introduced in Paris upon the arrival of the Russian Ballet in 1910 that typically used ocher and crimson shades. The start of the movie industry in Hollywood in the 1920s had a profound influence on cosmetics [13]. Movie stars such as Theda Bara - one of the most popular actresses of the silent movie era and one of cinema's earliest sex symbols - and her makeup artist Helena Rubinstein can be considered pioneers of the cosmetics industry [13]. Many other well-known manufacturers of beauty products such as Max Factor, Sr., Elizabeth Arden, Coco Chanel, and L'Oréal had their start in that period. Their products were in high demand and instilled selfawareness in American women of the 1920s. This led, among others, to the Flapper style which was characterized by daring dark eyes, red lipstick, and red nail polish, as well as a suntan [14] (Figure 3). Other accomplishments from that period are the eyebrow pencil, mascaras, synthetic hair dyes and nail polishes, as well as sunscreens.

Between 1939 and 1945 during the Second World War, cosmetics were in short supply throughout the entire world. This was for an important part attributable to the fact that petroleum and alcohol, basic ingredients of many beauty products, were desperately needed for the fabrication of fuels to fight the war. However, the post-war period led to a massive boom of the above-mentioned established corporations, but also to opportunities for newcomers such as Pond's who operated in the lower price range [15].

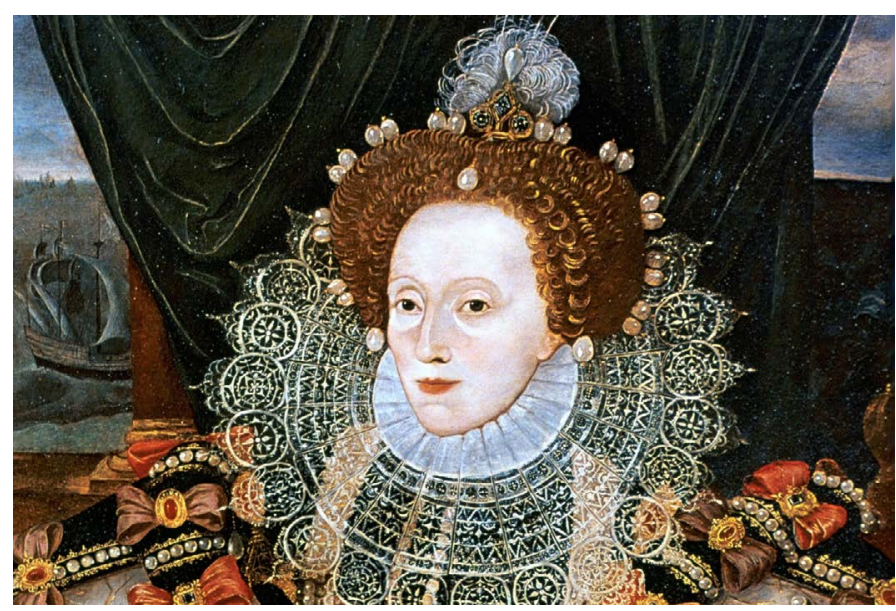

Figure 2. Queen Elizabeth I of England (1533 - 1603) wearing her 'mask of youth' (from https://goo.gl/images/prQZBY). 


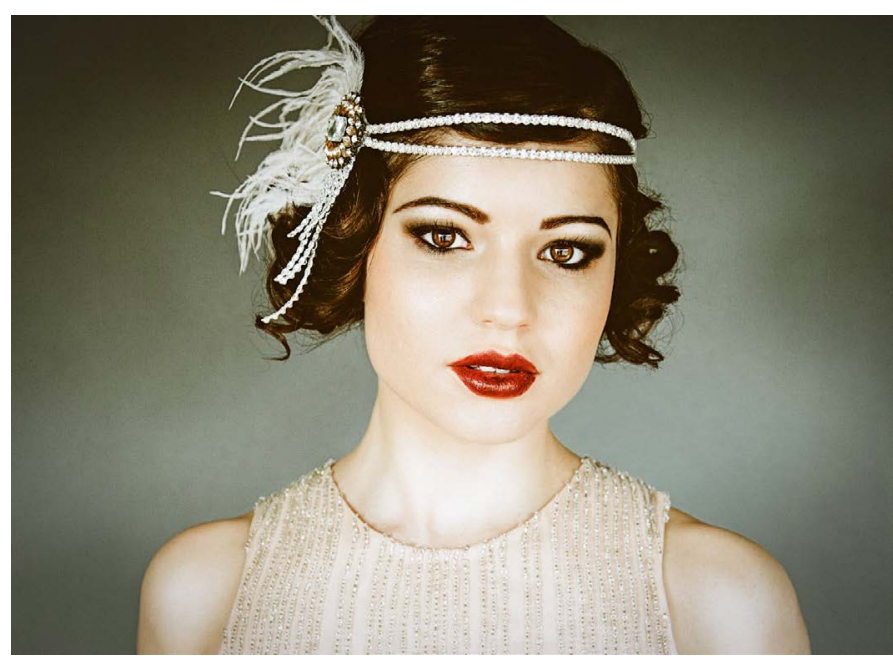

Figure 3. Characteristic 1920s Flapper style (from https://goo.gl/images/DbKy3d).

\section{The late twentieth century}

The feminism movement of the 1960s and 1970s led many women in the western world to abandon the use of beauty products as this would degrade women to sex objects [16]. One of the results of this trend was the development of more 'natural-looking' products in the 1970s. At the same time, non-allergic cosmetics and makeup with greater staying power in wear appeared, as well as new lipstick colors such as lilac, green, and silver rather than only the different shades of pink and red [16]. Also, an increasing number of males began to use cosmetics to enhance their facial features [17]. The concealer or color corrector developed to mask dark circles, age spots, large pores, and other small blemishes on the skin, became one of the most popular 'male cosmetics' [17].

\section{The twenty-first century}

The worldwide cosmetics and cosmeceuticals industry is currently among the largest in the world and had an estimated market price of over U\$ 200 billion in the year 2015 [18]. This value represented a growth of $4 \%$ when compared to the year before [18], which may be attributable to increases in global economies, changing lifestyles, and rising demands of skin and sun care products, as well as the exploitation of a new, profitable niche, naturally-derived beauty products. The leading markets are Asia and the Pacific region with a share of 36.9\%, followed by North America and Western Europe with proportions of 24.8 and 19.3\%, respectively [18]. Latin America, Eastern Europe, and Africa and the Middle East hold shares of 10.2, 6.0, and 2.9\%, respectively [18]. The main players in 2015 were the L'Oréal Group (U\$ 28.02 billion), Unilever (U\$ 20.47 billion), the Procter \& Gamble Company (U\$ 17.60 billion), Estée Lauder Companies, Inc. (U\$ 11.10 billion), and Shiseido Company, Ltd. (U\$ 7.11 billion) [18]. Skin care products accounted for $36.3 \%$ of global sales, hair care products for $22.9 \%$, makeup for $18.2 \%$, fragrances for $12.0 \%$, and hygiene products for $10.5 \%$ [18]. These products were most frequently purchased from general department stores, supermarkets, drug stores, and brand outlets, and more recently, also on-line stores [18].

\section{Back to the future}

An important development in the modern cosmetics and cosmeceuticals industry is the returning trend of using herbal ingredients in cosmetic and cosmeceutical products [19]. As mentioned above and extensively reviewed by others $[6,20,21]$, the use of herbal beauty products is centuries old and represents the basis of the modern cosmetics and cosmeceuticals industry. Extracts from parts of aromatic and medicinal plants have been incorporated in perfumes and beauty products since ancient times $[6,20,21]$. And since the revived interest in makeup from the early 1900s on, the significance of naturally-derived substances to the cosmetic and cosmeceutical industry has dramatically increased $[13,20]$. This trend accommodates the increasing demand for natural or organic products by customers throughout the entire world, as the use of botanical products is believed to carry a lesser risk of undesirable effects [22] and may help preserve the environment from the detrimental effects of chemical waste products [22,23].

\section{Background on Suriname}

\section{Geography, economy, and people}

The Republic of Suriname has a surface area of approximately $165,000 \mathrm{~km}^{2}$, is located on the north-east coast of South America and borders the Atlantic Ocean, and is situated adjacent to French Guiana, Guyana, and Brazil (Figure 4). Roughly $80 \%$ of the population of about 570,000 lives in the urban-coastal area comprising the capital city of Paramaribo and the Wanica district located in the narrow low-land coastal zone in the northern part of the country (Figure 4) [24]. The rural-coastal area of Suriname includes the districts of Marowijne, Commewijne, Saramacca, Coronie, and Nickerie (Figure 4), and is, together with the southern-rural interior consisting of the districts of Para, Brokopondo, and Sipaliwini (Figure 4), home to the remaining $20 \%$ of Suriname's inhabitants [24].

The latter part of the country (the hinterland) comprises more than three-quarters of Suriname's land surface, consists largely of sparsely inhabited savanna and dense, pristine tropical rain forest, contains high-quality fresh water and clean air, and harbors many endemic animal and plant species [25]. Suriname's very high biodiversity, notoriously fertile soils, and high mineral density sustain its most important means of subsistence, namely ecotourism, agriculture,

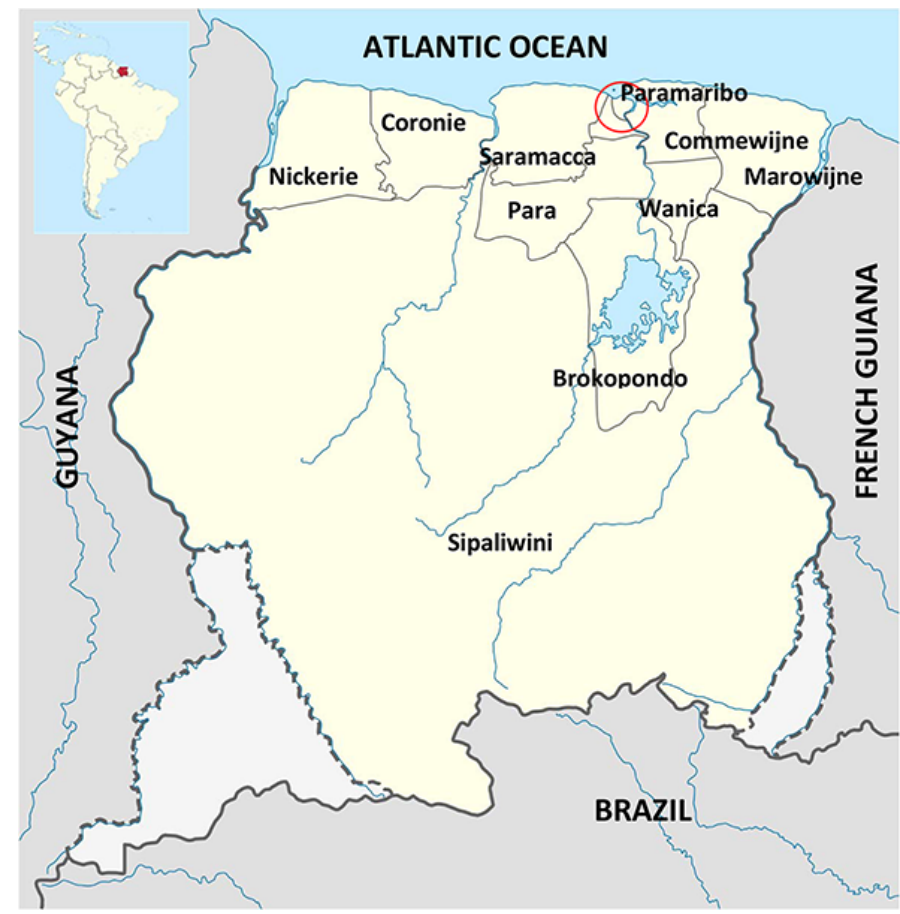

Figure 4. Map of the Republic of Suriname depicting the ten administrative districts as well as the location of the country in South America (insert). 
fisheries, forestry, crude oil drilling, as well as gold and bauxite mining [26]. These activities contributed substantially to the country's gross domestic income in 2015 of U\$ 5.15 billion and the average per capita income in that year of U\$9,360 [26,27]. This positions Suriname on the World Bank's list of upper middle income economies [27].

Suriname is one of the smallest countries of South America. Nevertheless, it is renowned for its ethnic diversity comprising indigenous Amerindians; descendants from enslaved Africans brought in between the sixteenth and the nineteenth century called Creoles and Maroons; descendants from indentured laborers from China, India, and Indonesia who arrived between the second half of the nineteenth century and the first half of the twentieth century; descendants from various European countries; and more recently, immigrants from Latin American and Caribbean counties such as Brazil, Guyana, French Guiana, and Haiti [28]. All these ethnic groups have largely preserved their own specific identity including their ethnopharmacological practices [29]. This may result in an unique blend of traditional medicinal systems and an entirely novel form of complementary and alternative medicine [29].

\section{Traditional medicine in Suriname}

Despite the availability of affordable primary and secondary health care in both Suriname's coastal area and hinterland [30], the use of traditional medicines is deeply rooted in all ethnic groups and in all parts of Suriname. For instance, the centuries-old medicinal traditions of the indigenous Amerindians involve the use of more than three hundred plant species for treating approximately seventy-five distinct disease conditions and are still very much alive [31]. Importantly, many Amerindian disease descriptions closely correspond with those in Western allopathic medicine, and the treatments are often successful [31]. An example is the indigenous use of the dried leaves of the bitter melon Momordica charantia L. (Cucurbitacea) (Figure 5) for treating the symptoms of diabetes mellitus, which is supported by the hypoglycemic effects of $M$. charantia preparations in various animal models [32].

Many traditional medicinal practices of Afro-Surinamese can directly be traced back to the ancient African belief that both physiological and psychological conditions result from an imbalance between 'hot' and 'cold' and can be reversed by removing the 'cold' [33].

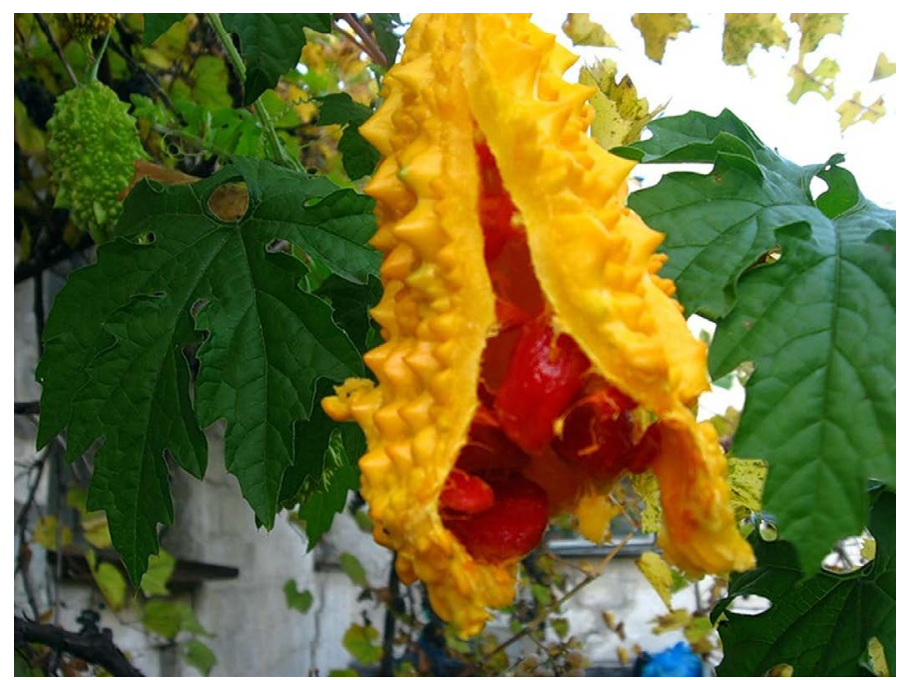

Figure 5. The bitter melon Momordica charantia L. (Cucurbitacea) (from https://goo.gl/ images/jLZSoR).
Accordingly, Surinamese Creoles and Maroons may 'remove colds' and promote general health using kwasibita ('Kwasi's bitter'), an alcoholic extract of the bitterwood of Quassia amara L. (Simaroubaceae) [34]. This preparation was discovered around 1730 by the freedman Quassie van Timotibo (also known as Kwasi) who had successfully used it for treating malaria fevers and stomach troubles [35].

Examples of the dozens of medicinal plants introduced in Suriname by the Hindustani and the Javanese - the descendants from indentured laborers from India and Java (Indonesia), respectively - are the neem plant Azadirachta indica A. Juss. (Meliaceae) and the laos Alpinia galanga (L.) Willd. (Zingiberaceae), respectively. The bitter-tasting A. indica leaves are believed to boost the immune system and to treat, among others, colds, fevers, respiratory conditions, and chicken pox $[36,37]$. These applications may find their rationale in the anthelmintic, antifungal, antibacterial, and antiviral activities of nimbinin, one of the main bioactive compounds of $A$. indica [38]. The rhizomes of $A$. galanga are extensively used for treating the fungal skin infection 'lota' (pityriasis alba), as well as stomach cramps and dysentery [39]. This may be attributed to the potent antiparasitic properties of galangin, one of the bioactiove constituents of this plant [40]. These applications have their origin in Indian Ayurveda and Indonesian Jamu, respectively.

An important medicinal plant introduced in Suriname by Chinese indentured laborers is the Mongolian milkvetch or huáng qí Astragalus propinquus Schischkin (Fabaceae). This plant is one of the fifty fundamental herbs of traditional Chinese medicine, and the rhizomes have since long been used in traditional Chinese medicinal systems [41]. Huáng qí preparations would strengthen the vital energy Qi and are commonly used for general health and well-being, to increase stamina and endurance, to stimulate the immune system, to prevent colds and upper respiratory infections, and to lower blood pressure and blood sugar levels $[42,43]$.

\section{Herbal cosmetics and cosmeceuticals in Suriname}

\section{Literature data on plant-derived cosmetics and cosmeceuticals}

The examples mentioned in the preceding paragraph illustrate the rich and diverse traditional medicinal systems in Suriname and the wide variety of plants that are employed for medicinal purposes in the country. The use of these plants by Creoles and Maroons, Hindustani, and Javanese has comprehensively been addressed by van Andel and Ruysschaert [44] and van 't Klooster [45], Raghoenandan [46], and Tjong Ayong [39], respectively. Together, these publications have compiled 789 Surinamese medicinal plants, seventy-two of which (roughly 10\%) are used for cosmetic and cosmeceutical purposes.

The latter plants are given in Table 1, which further shows that the majority of them (fifty-eight or more than three-quarters) is used as cosmeceuticals, i.e., for treating pimples, warts, scars, and pigment spots; flaky skin; skin irritation such as rash, dermatitis, and eczema; local skin lesions such as boils and pustules; as well skin fungi and skin parasites. This is understandable when considering that these plants are mainly mentioned in publications dealing with plants having medicinal properties. These 'cosmeceutical' plants belong to more than twenty-five different plant families, which indicates the usefulness of Surinamse medicinal plants for treating (facial) skin problems. The remaining fourteen of the seventy-two 'cosmetic' and 'cosmeceutical' plants (about 20\%) is used for 'genuine' cosmetic purposes, i.e., as makeup, for masking body odor, for skin and hair care, for skin refreshment and rejuvenation, and in genital steam baths. 
Table 1. Compiled literature data on plants used for cosmetic and cosmeceutical purposes in Suriname (39,44-46).

\begin{tabular}{|c|c|c|}
\hline Condition & Plant (vernacular name in English; Surinamese) & Family \\
\hline Body odor & Psidium guajava L. (guava; guyaba) & Myrtaceae \\
\hline Flaky skin & $\begin{array}{l}\text { Erechtites hieracifolia (L.) Riaf.ex DC. (fireweed; } \\
\text { leta wiwiri) } \\
\text { Senna alata (L.) Roxb. (candle bush; slabriki) }\end{array}$ & $\begin{array}{l}\text { Asteraceae } \\
\text { Fabaceae }\end{array}$ \\
\hline $\begin{array}{l}\text { Genital steam } \\
\text { baths }\end{array}$ & $\begin{array}{l}\text { Tripogandra serrulata (Vahl.)Handlos (pink trinity; } \\
\text { redi gadodede) }\end{array}$ & Commelinaceae \\
\hline Hair care & $\begin{array}{l}\text { Maximiliana maripa (Correa) Drude. (maripa palm; } \\
\text { maripa) } \\
\text { Morinda citrifolia } \text { L. (noni; didibri apra) } \\
\text { Bertholletia excelsa } \text { Humb. \& Bonpl. (Brazilian nut; } \\
\text { paranoto) }\end{array}$ & $\begin{array}{l}\text { Arecaceae } \\
\text { Rubiaceae } \\
\text { Lecythidaceae }\end{array}$ \\
\hline $\begin{array}{l}\text { Local skin } \\
\text { lesions } \\
\text { (e.g., boils and } \\
\text { pustules) }\end{array}$ & $\begin{array}{l}\text { Mangifera indica L. (mango; manya) } \\
\text { Mikania micrantha Kunth (bitter vine; brokobaka) } \\
\text { Sphagneticola trilobata } \text { (L) Pruski (creeping daisy; } \\
\text { kromanti wiwiri) } \\
\text { Unxia camphorata } \text { L.f. (sand bitters; masangobita) } \\
\text { Momordica charantia L. (bitter melon; wilde } \\
\text { sopropo) } \\
\text { Senna alata } \text { (L.) Roxb. (candle bush; slabriki) } \\
\text { Azadirachta indica A. Juss. (neem; nim) } \\
\text { Cedrela odorata } \text { L. (Spanish cedar; redi krapa) } \\
\text { Cymbopogon citratus (Dc) Stapf. (lemon grass; } \\
\text { citroengras) } \\
\text { Citrus } \text { sp. } \\
\text { Cecropia } \text { sp. }\end{array}$ & $\begin{array}{l}\text { Anacardiaceae } \\
\text { Asteraceae } \\
\text { Asteraceae } \\
\text { Asteraceae } \\
\text { Cucurbitaceae } \\
\text { Fabaceae } \\
\text { Meliaceae } \\
\text { Meliaceae } \\
\text { Poaceae } \\
\text { Rutaceae } \\
\text { Urticaceae }\end{array}$ \\
\hline Makeup & $\begin{array}{l}\text { Bixa orellana L. (lipstick plant; kusuwe) } \\
\text { Zea mays L. (corn; karu) }\end{array}$ & $\begin{array}{l}\text { Bixaceae } \\
\text { Poaceae }\end{array}$ \\
\hline Pigment spots & $\begin{array}{l}\text { Sida rhombifolia L. (Cuban jute; wadiwad) } \\
\text { Cedrela odorata L. (Spanish cedar; redi krapa) }\end{array}$ & $\begin{array}{l}\text { Malvaceae } \\
\text { Meliaceae }\end{array}$ \\
\hline Pimples & 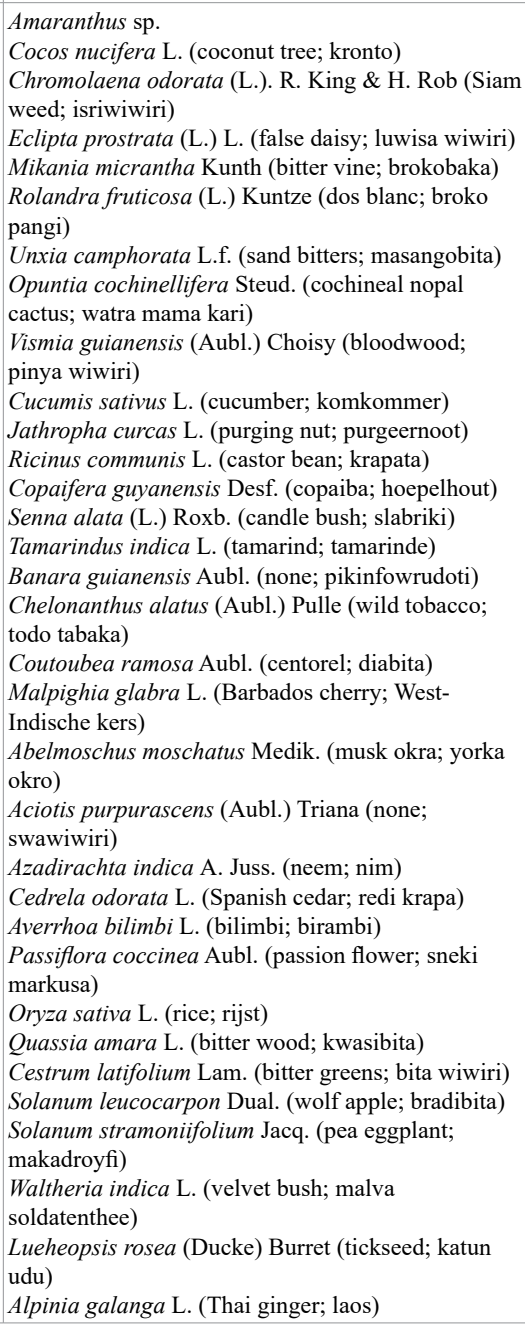 & $\begin{array}{l}\text { Amaranthaceae } \\
\text { Arecaceae } \\
\text { Asteraceae } \\
\text { Asteraceae } \\
\text { Asteraceae } \\
\text { Asteraceae } \\
\text { Asteraceae } \\
\text { Cactaceae } \\
\text { Clusiaceae } \\
\text { Cucurbitaceae } \\
\text { Euphorbiaceae } \\
\text { Euphorbiaceae } \\
\text { Fabaceae } \\
\text { Fabaceae } \\
\text { Fabaceae } \\
\text { Salicaceae } \\
\text { Gentianaceae } \\
\text { Gentianacea } \\
\text { Malpighiaceae } \\
\text { Malvaceae } \\
\text { Melastomataceae } \\
\text { Meliaceae } \\
\text { Meliaceae } \\
\text { Oxalidaceae } \\
\text { Passifloraceae } \\
\text { Poaceae } \\
\text { Simarubaceae } \\
\text { Solanaceae } \\
\text { Solanaceae } \\
\text { Solanaceae } \\
\text { Sterculiaceae } \\
\text { Tiliaceae } \\
\text { Zingiberacea }\end{array}$ \\
\hline
\end{tabular}

\begin{tabular}{|c|c|c|}
\hline Scars & $\begin{array}{l}\text { Aloe vera }(\mathrm{L}) \text { Burm.f. (aloë; aloe) } \\
\text { Cedrela odorata } \text { L. (Spanish cedar; redi krapa) } \\
\text { Alpinia galang } \text { L. (Thai ginger; laos) }\end{array}$ & $\begin{array}{l}\text { Asphodelaceae } \\
\text { Meliaceae } \\
\text { Zingiberacea }\end{array}$ \\
\hline Skin care & $\begin{array}{l}\text { Eryngium foetidum L. (culantro; sneki wiwiri) } \\
\text { Cocos nucifera } \text { L. (coconut tree; kronto) } \\
\text { Euterpe oleracea Mart. (acai; podosiri) } \\
\text { Maximiliana maripa (Correa) Drude. (maripa palm; } \\
\text { maripa) } \\
\text { Morinda citrifolia } \text { L. (noni; didibri apra) } \\
\text { Laportea aestuans } \text { (L.) Chew. (West Indian wood } \\
\text { nettle; krasiwiwiri) }\end{array}$ & $\begin{array}{l}\text { Apiaceae } \\
\text { Arecaceae } \\
\text { Arecaceae } \\
\text { Arecaceae } \\
\text { Rubiaceae } \\
\text { Urticaceae }\end{array}$ \\
\hline Skin fungi & $\begin{array}{l}\text { Allium sativum L. (garlic; knoflook) } \\
\text { Lablab purpureus (L.) Sweet (hyacinth bean; } \\
\text { komata) } \\
\text { Senna alata }(\text { L.) Roxb. (candle bush; slabriki) } \\
\text { Senna reticulata (Willd.) HS Irwin et Barneby } \\
\text { (carrion crow bush; slabriki) }\end{array}$ & $\begin{array}{l}\text { Amaryllidaceae } \\
\text { Fabaceae } \\
\text { Fabaceae } \\
\text { Fabaceae }\end{array}$ \\
\hline Skin parasites & $\begin{array}{l}\text { Unxia camphorata L.f. (sand biters; masangobita) } \\
\text { Carapa guianensis Aubl. (crabwood; krapa) }\end{array}$ & $\begin{array}{l}\text { Asteraceae } \\
\text { Meliaceae }\end{array}$ \\
\hline $\begin{array}{l}\text { Skin irritation } \\
\text { (e.g., rash, } \\
\text { dermatitis, and } \\
\text { eczema) }\end{array}$ & $\begin{array}{l}\text { Eclipta prostrata (L.) L. (false daisy; luwisa wiwiri) } \\
\text { Mikania micrantha Kunth. (bitter vine; brokobaka) } \\
\text { Unxia camphorata L.f. (sand bitters; masangobita) } \\
\text { Crescentia cujete L. (calabash; krabasi) } \\
\text { Bixa orellana L. (lipstick plant; kusuwe) } \\
\text { Tournefortia ulei Vaupel. (West Indian soldierbush; } \\
\text { alamankina) } \\
\text { Commelina difussa } \text { Burm.f. (climbing dayflower; } \\
\text { gadodede) } \\
\text { Cnidoscolus urens (L.) J.C. Arthur. (bull nettle; } \\
\text { krasiwiwiri) } \\
\text { Maprounea guianensis Aubl. (awati; dek' ati) } \\
\text { Senna alata (L.) Roxb. (candle bush; slabriki) } \\
\text { Leonotis nepetifolia (L) R. Br. (lion's ear; bradi bita) } \\
\text { Ocimum tenuiflorum L. (holy basil; tulsi) } \\
\text { Abelmoschus moschatus Medik. (musk okra; yorka } \\
\text { okro) } \\
\text { Azadirachta indica A. Juss. (neem; nim) } \\
\text { Carapa guianensis Aubl. (crabwood; krapa) } \\
\text { Cedrela odorata L. (Spanish cedar; redi krapa) } \\
\text { Ficus schumacheri (Liebm.) Griseb. (bearded fig; } \\
\text { kromanti obya) } \\
\text { Piper marginatum Jacq. (marigold pepper; aneysi } \\
\text { wiwiri) }\end{array}$ & $\begin{array}{l}\text { Asteraceae } \\
\text { Asteraceae } \\
\text { Asteraceae } \\
\text { Bignoniaceae } \\
\text { Bixaceae } \\
\text { Boraginaceae } \\
\text { Commelinaceae } \\
\text { Euphorbiaceae } \\
\text { Euphorbiaceae } \\
\text { Fabaceae } \\
\text { Lamiaceae } \\
\text { Lamiaceae } \\
\text { Malvaceae } \\
\text { Meliaceae } \\
\text { Meliaceae } \\
\text { Meliaceae } \\
\text { Moraceae } \\
\text { Piperaceae }\end{array}$ \\
\hline $\begin{array}{l}\text { Skin } \\
\text { refreshment }\end{array}$ & $\begin{array}{l}\text { Plectranthus amboinicus } \text { Lour. (thick leaf thyme; } \\
\text { dekminti) } \\
\text { Gossypium barbadense L. (sea island cotton; redi } \\
\text { katun) } \\
\text { Orchid spp. (orchid; orchidee) }\end{array}$ & $\begin{array}{l}\text { Lamiaceae } \\
\text { Malvaceae } \\
\text { Orchidaceae }\end{array}$ \\
\hline $\begin{array}{l}\text { Skin } \\
\text { rejuvenation }\end{array}$ & $\begin{array}{l}\text { Phtirusa stellis (G.Mey) Maguire (mistletoe; pikin } \\
\text { fowrudoti) } \\
\text { Laportea aestuans (L.) Chew. (West Indian wood } \\
\text { nettle; krasiwiwiri) }\end{array}$ & $\begin{array}{l}\text { Loranthaceae } \\
\text { Urticaceae }\end{array}$ \\
\hline Warts & $\begin{array}{l}\text { Asclepias curassavica L. (tropical milkweed; } \\
\text { koningsbloempje) } \\
\text { Plumeria acuminata Ait. (temple tree; franchepane) } \\
\text { Commelina difussa } \text { Burm.f. (climbing dayflower; } \\
\text { gadodede) } \\
\text { Bryophyllum pinnatum (Lam) Oken. (mother of } \\
\text { thousands; wonderblad) } \\
\text { Gossypium barbadense L. (sea island cotton; redi } \\
\text { katun) }\end{array}$ & $\begin{array}{l}\text { Apocynaceae } \\
\text { Apocynaceae } \\
\text { Commelinaceae } \\
\text { Crassulaceae } \\
\text { Malvaceae }\end{array}$ \\
\hline
\end{tabular}

\section{Production of plant-derived cosmetics and cosmeceuticals}

The data mentioned in the preceding paragraphs indicate that there is ample raw plant material in Suriname that can be processed into medicinal preparations as well as cosmetics and cosmeceuticals. As a result, an increasing number of individuals and small and medium-sized enterprises earn their living in the medicinal plants sector in the country [47]. They either cultivate and/or collect the raw materials themselves and act as suppliers for retailers or middlemen, or are involved in the processing and/or fabrication of semi-finished or end-products [47].

According to the Surinamese Chamber of Commerce and Industry, there are at this moment nineteen companies in Suriname - in general, 
small business - that manufacture herbal medicines [48]. Interviews with the managers of these companies at the Made in Suriname Fair of 2016 indicated that four of them are involved in the production of facial care products, namely Jomi Cosmetics, Jedally's Cosmetics, Skin Glanz Cosmetics, and Odany Jewa [49]. Jomi Cosmetics has specialized in facial cosmetics and cosmeceuticals from the start (Figure 6), some fourteen years ago, but the other companies only started relatively recently with these activities, even though they are for some years active on the herbal market [49]. The managers have acquired their knowledge and skills about skin care and skin care products either from their ancestors, or by following (accredited) courses and trainings on cosmetic sciences, herbalism, and/or beautifying in specialized institutions in, among others, The Netherlands and Germany [49]. Their products are distributed through a wide network of retailers in Suriname, and in the case of Jomi Cosmetics, also in French Guiana, Brazil, Antiqua, and The Netherlands [49].

Together, Jomi Cosmetics, Jedally's Cosmetics, Skin Glanz Cosmetics, and Odany Jewa manufacture a broad assortment of cosmetics and cosmeceuticals for facial care [49]. This includes facial cleaners, facial washes and scrubs, face masks, and several day and night creams, as well as ointments to remove impurities in the face, eye bags, liver spots, etc. [49]. Jomi Cosmetics offers the broadest assortment of facial care products [49]. In all cases, information about the raw materials used, indications, contraindications, and potential side-effects (such as allergic skin reactions including photosensitivity reactions) are properly indicated on the instructions for use [49]. Some of the companies also offer standard facial treatments as well as therapies for acne, wrinkles, and ageing skin [49]. Cases of severe infections are referred to a general physician or a dermatologist [49].

The beauty products are mostly prepared from fresh fruits, fresh plant parts or constituents, as well as semi-finished products such as vegetable oils and waxes from twenty-two plants (Table 2) [49]. The use as cosmetics and/or cosmeceuticals of some of them has already been mentioned in Table 1. The scientific rationale for using these plants is addressed later in this paper. The raw plant materials are procured from cultivators, collectors, and vendors on contract who mainly operate in the districts of Para, Sipaliwini, Brokopondo, and Marowijne [49]. In these parts of Suriname, many of the plants can easily be grown and are

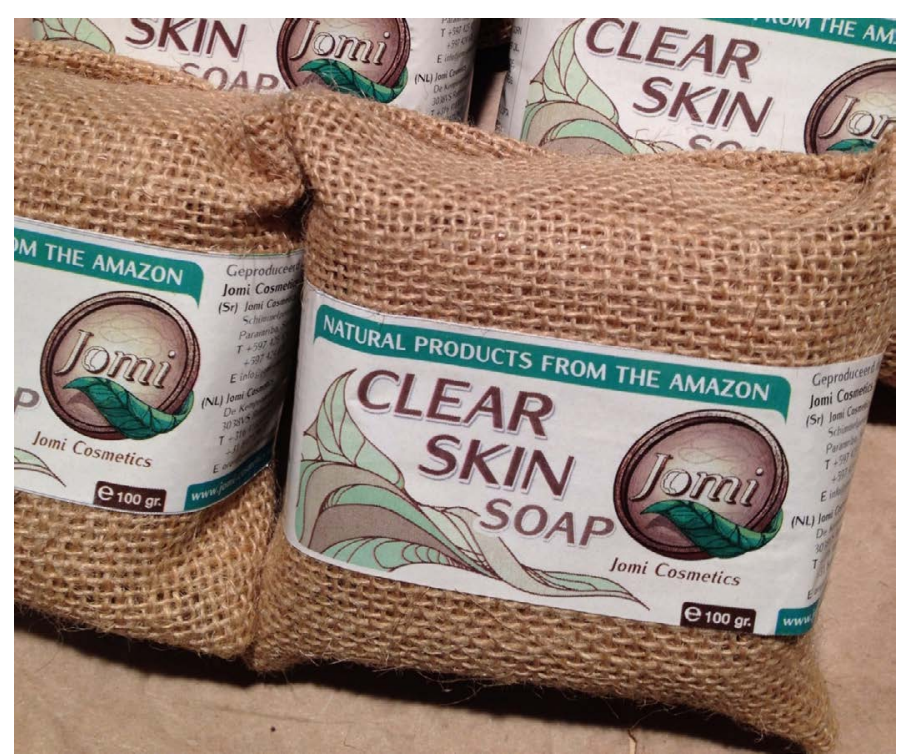

Figure 6. Beauty products from Jomi Cosmetics, Suriname (from https://goo.gl/images/ dKWVjR). relatively frequently encountered in the wild. An exception is the West Indian wood nettle L. aestuans that is relatively rare [49].

Other important ingredients such as the oils extracted from the coconut tree C. nucifera, the crabwood C. guianensis, and the copaiba C. guyanensis Desf. (Fabaceae) require elaborate processing [49]. Still others such as shea butter (a fat extracted from the seeds of the African shea tree Vitellaria paradoxa C.F.Gaertn. (Sapotaceae)), jojoba oil (a liquid wax from the seeds of the jojoba Simmondsia chinensis (Link) C. K. Schneid. (Simmondsiaceae)), and grapeseed oil (the oil extracted from grape seeds as a by-product of winemaking) are not available in Suriname and must be imported [49].

\section{Ingredients of plant-based cosmetics and cosmeceuticals}

The most commonly used plants for manufacturing cosmetics and cosmeceuticals in Suriname are mentioned in Table 2 and have been dealt with in ref. 49. Fresh leaves of A. vera, A. indica, C. citratus, $M$. oleifera, and/or T. indica, along with coconut oil are typically included in facial washes. The leaves of $C$. citratus are also used to prepare facial milks, as are those of $P$. amboinicus. The juice from the fruits of $C$. nucifera, C. sativus, E. oleracea, $M$. citrifolia, certain orchid specis, and extracts from the leaves of T. indica and A. indica, and the calyces of $H$, sabdariffa L. are used to prepare day and night creams.

The finely ground granules from E. oleracea fruits are the main ingredients of an exfoliant to remove dead skin cells and stimulate blood circulation, forming the basis of facial scrubs. The leaf juices of E. prostata, S. alata, and T. indica are essential components of deep skin cleaners. Extracts from the leaves of L. aestuans and M. oleifera are important ingredients of formulations for treating acne, eczema, scars, insect bites, and chapped lips. Preparations from T. serrulata leaves or whole plant are included in hair growth-stimulating products. Notably, many of the above-mentioned substances are also incorporated in other skin care products, creams for skin regeneration, and anti-ageing lotions.

The oils extracted from the fruits or seeds of B. excelsa, C. nucifera, C. guianensis, and M. maripa, and that from the trunk of C. guyanensis, give Brazil nut oil, coconut oil, krapa oil, maripa oil, and hoepel oil, respectively, and are locally manufactured semi-finished products. These substances are abundantly used for hair care and the production of soaps, and are, together with extracts from A. indica, L. nepetifolia and/or B. pinnatum leaves, included in eye masks as well as ointments for treating eye bags and acne.

Examples of imported semi-finished ingredients are shea butter, jojoba oil, and grapeseed oil. These substances are widely used for skinand hair-related products such as soaps, skin moisturizers, sunscreens, lip balms, anti-wrinkle formulations, anti-stretch mark creams, hair conditioners, baby oils, and ointments against skin inflammation [5052]. They are also, together with the leaf juice from $A$. indica and/or $P$. amboinicus, common constituents of facial masks.

\section{Scientific rationale for using Surinamese plants as cosmetics and cosmeceuticals}

The scientific rationale for the cosmetic and cosmeceutical use of the above-mentioned plants based on their phytochemical composition is extensively presented in this section. The data are summarized in Table 3.

\section{Aloe vera (L) Burm.f.}

Parts of A. vera are abundantly used in traditional medicinal systems as a treatment for, among others, microbial infections, 
Table 2. Plants used for manufacturing cosmetics and cosmeceuticals in Suriname.

\begin{tabular}{|c|c|c|}
\hline $\begin{array}{l}\text { Plant species (vernacular name in English; } \\
\text { Surinamese) }\end{array}$ & Plant family & Main cosmetic /cosmeceutical use in Suriname \\
\hline $\begin{array}{l}\text { Aloë vera (L.) Burm.f. } \\
\text { (aloe; aloe) }\end{array}$ & Asphodelaceae & Skin care products, facial washes, day and night creams, skin regeneration and anti-ageing creams \\
\hline $\begin{array}{l}\text { Azadirachta indica A.Juss., } 1830 \\
\text { (neem; nim) }\end{array}$ & Meliaceae & Facial washes, facial masks, eye masks, day and night creams, anti-eye bag products, anti-acne creams \\
\hline $\begin{array}{l}\text { Bertholletia excelsa Humb. \& Bonpl. } \\
\text { (Brazilian nut; paranoto) }\end{array}$ & Lecythidaceae & Soaps, skin care products, eye masks, anti-eye bag products, anti-acne creams, hair care products \\
\hline $\begin{array}{l}\text { Bryophyllum pinnatum (Lam) Oken. } \\
\text { (mother of thousands; wonderblad) }\end{array}$ & Crassulaceae & Skin care products, skin regeneration products, eye masks, anti-eye bag products, anti-acne creams \\
\hline $\begin{array}{l}\text { Carapa guianensis Aubl. } \\
\text { (crabwood; krapa) }\end{array}$ & Meliaceae & $\begin{array}{l}\text { Soaps, skin care products, skin regeneration creams, eye masks, anti-eye bag products, anti-acne creams, } \\
\text { anti-cellulite formulations, hair care products }\end{array}$ \\
\hline $\begin{array}{l}\text { Cocos nucifera } \mathrm{L} \text {. } \\
\text { (coconut tree; kronto) }\end{array}$ & Arecaceae & $\begin{array}{l}\text { Soaps, skin care products, facial washes, facial masks, eye masks, day and night creams, skin } \\
\text { regeneration and anti-ageing creams, eye masks, anti-eye bag products, anti-acne creams hair care } \\
\text { products }\end{array}$ \\
\hline $\begin{array}{l}\text { Copaifera guyanensis Desf. } \\
\text { (copaiba; hoepelhout) }\end{array}$ & Fabaceae & Soaps, eye masks, anti-eye bag products, anti-acne creams, hair care products \\
\hline $\begin{array}{l}\text { Cucumis sativus } \mathrm{L} . \\
\text { (cucumber; komkommer) }\end{array}$ & Cucurbitaceae & Skin care products, day and night creams, skin regeneration creams \\
\hline $\begin{array}{l}\text { Cymbopogon citratus }(\mathrm{Dc}) \text { Stapf. } \\
\text { (lemon grass; citroengras) }\end{array}$ & Poaceae & Facial washes; facial milks \\
\hline $\begin{array}{l}\text { Eclipta prostata }(\mathrm{L} .) \mathrm{L} . \\
\text { (false daisy; luisawiwiri) }\end{array}$ & Asteraceae & Deep skin cleaners \\
\hline $\begin{array}{l}\text { Euterpe oleracea } \text { Mart. } \\
\text { (acai; podosiri) }\end{array}$ & Arecaceae & $\begin{array}{l}\text { Skin care products, facial scrubs, day and night creams, skin regeneration and anti-ageing creams, hair } \\
\text { care products }\end{array}$ \\
\hline $\begin{array}{l}\text { Hibiscus sabdariffa L. } \\
\text { (roselle; syuru) }\end{array}$ & Malvaceae & Skin care products, day and night creams, skin protection creams, anti-ageing creams, hair care products \\
\hline $\begin{array}{l}\text { Laportea aestuans }(\mathrm{L}) \text { Chew. } \\
\text { (West Indian wood nettle; brandnetel) }\end{array}$ & Urticaceae & Skin care products, anti-acne creams, anti-eczema formulations, lip balms \\
\hline $\begin{array}{l}\text { Leonotis nepetifolia }(\mathrm{L}) \mathrm{R} . \mathrm{Br} \text {. } \\
\text { (lion's ear; bradi bita) }\end{array}$ & Lamiaceae & Eye masks, anti-eye bag products, anti-acne creams \\
\hline $\begin{array}{l}\text { Maximiliana maripa (Correa) Drude. } \\
\text { (maripa palm; maripa) }\end{array}$ & Arecaceae & Soaps, eye masks, anti-eye bag products, anti-acne creams, hair care products \\
\hline $\begin{array}{l}\text { Morinda citrifolia } \mathrm{L} \text {. } \\
\text { (noni; didibri apra) }\end{array}$ & Rubiaceae & $\begin{array}{l}\text { Skin care products, facial washes, day and night creams, skin regeneration and anti-ageing creams, anti- } \\
\text { acne creams, hair care products, deodorants }\end{array}$ \\
\hline $\begin{array}{l}\text { Moringa oleifera Lam. } \\
\text { (moringa; moringa) }\end{array}$ & Moringaceae & Facial washes, acne, eczema, scars, insect bites, lip balms \\
\hline Orchid spp. & Orchidaceae & Skin care products, skin regeneration and anti-ageing creams \\
\hline $\begin{array}{l}\text { Plectranthus amboinicus Lour. } \\
\text { (thick leaf thyme; dekminti) }\end{array}$ & Lamiaceae & Anti-acne creams \\
\hline $\begin{array}{l}\text { Senna alata }(\text { L.) Roxb. } \\
\text { (candle bush; slabriki) }\end{array}$ & Fabaceae & Deep skin cleaners \\
\hline $\begin{array}{l}\text { Tamarindus indica } \mathrm{L} . \\
\text { (tamarind; tamarinde) }\end{array}$ & Fabaceae & $\begin{array}{l}\text { Skin care products, facial washes, face masks, day and night creams, deep skin cleaners, skin regeneration } \\
\text { and anti-ageing creams, lip balms, sun screens }\end{array}$ \\
\hline $\begin{array}{l}\text { Tripogandra serrulata (Vahl.)Handlos } \\
\text { (pink trinity; redi gadodede) }\end{array}$ & Commelinaceae & Hair growth promotion products \\
\hline
\end{tabular}

constipation, diabetes mellitus, and skin conditions [53,54]. Their alleged therapeutic efficacy may be associated with the presence in the leaves of phytochemicals such as acetylated mannans, polymannans, anthraquinones, and lectins [55,56]. For this reasons, the leaf gel is included in various health-promoting beverages and dietary supplements to support digestion [57]. It is furthermore used for manufacturing disposable facial tissues, makeup, moisturizers, soaps, sunscreens, shaving creams, shampoos, skin lotions, and ointments for minor burns and sunburns [55-59]. These applications are presumably based on the soothing, moisturizing, and emollient effects of $A$. vera leaf gel $[58,59]$ which may particularly be associated with the polysaccharides in the gel [58,59].

\section{Azadirachta indica A. Juss.}

Preparations from the leaves of the neem A. indica have been used in Indian Ayurveda for over two millennia against a wide variety of diseases, ranging from colds, fevers, and respiratory conditions to high blood pressure and diabetes mellitus $[36,37,60]$. The oil extracted from A. indica fruits and seeds has been used as a folk medicine against acne and redness and inflammation of the skin $[36,37,61]$. These beneficial effects may be related to the antiparasitic and antimicrobial activities of the limonoids azadirachtin and nimbinin in the leaves $[38,62]$, as well as the soothing and moisturizing effects of oleic acid, linoleic acid, stearic acid, and palmitic acid in the oil [62]. As a result, neem oil is used for preparing a large variety of cosmetics such as soaps, shampoos, balms, creams as well as toothpastes and nail polishes [63].

\section{Bertholletia excelsa Humb. \& Bonpl.}

The edible seeds of the Brazilian nut $B$. excelsa are rich in dietary fiber, vitamins, and dietary minerals, and are a staple diet of the natives residing in the Amazon forest [64]. The seeds are also commercially harvested and included in mixed nuts and confections coated with chocolate [64]. The oil extracted from the seeds contains $75 \%$ unsaturated fatty acids composed mainly of oleic and linoleic acids, as well as phytosterols, several phenolic compounds, vitamin E, and remarkably high levels of selenium [65-67]. It is used in creams, lotions, conditioners, and hair care products, as well as in formulations for alleviating dry, flaky skin, ageing skin, acne, and skin inflammation. 
Table 3. Plants and main plant part(s) used for manufacturing cosmetics and cosmeceuticals in Suriname and their presumed key active constituent(s).

\begin{tabular}{|c|c|c|}
\hline Plant species & Main plant part(s) used & $\begin{array}{l}\text { Presumed key active } \\
\text { constituent(s) }\end{array}$ \\
\hline Aloe vera $(\mathrm{L})$ Burm.f. & Gel from fresh leaves & Polysaccharides \\
\hline Azadirachta indica A. Juss. & $\begin{array}{l}\text { Extracts from fresh leaves, } \\
\text { seed oil }\end{array}$ & Limonoids \\
\hline $\begin{array}{l}\text { Bertholletia excelsa Humb. } \\
\text { \& Bonpl. }\end{array}$ & Seed oil & $\begin{array}{l}\text { Fatty acids, phenolic } \\
\text { compounds, vitamin E }\end{array}$ \\
\hline $\begin{array}{l}\text { Bryophyllum pinnatum } \\
\text { (Lam) Oken. }\end{array}$ & Extracts from fresh leaves & Glycosides, saponins \\
\hline Carapa guianensis Aubl. & Seed oil & Limonoids, fatty acids \\
\hline Cocos nucifera $\mathrm{L}$. & $\begin{array}{l}\text { Extracts from fresh fruits, } \\
\text { seed oil }\end{array}$ & $\begin{array}{l}\text { Phenolic compounds, } \\
\text { vitamin E, terpenes, } \\
\text { saponins }\end{array}$ \\
\hline Copaifera guyanensis Desf. & Trunk oil & Terpenes \\
\hline Cucumis sativus L. & Extracts from fresh fruits & Water, antioxidants \\
\hline $\begin{array}{l}\text { Cymbopogon citratus (Dc) } \\
\text { Stapf. }\end{array}$ & Extracts from fresh leaves & Essential oils \\
\hline Eclipta prostata (L.) L. & Extracts from fresh leaves & $\begin{array}{l}\text { Coumestans, glycosides, } \\
\text { amyrins }\end{array}$ \\
\hline Euterpe oleracea Mart. & $\begin{array}{l}\text { Extracts from fresh fruits, } \\
\text { ground seeds }\end{array}$ & Anthocyanins \\
\hline Hibiscus sabdariffa $\mathrm{L}$. & Extracts from fresh calyces & $\begin{array}{l}\text { Anthocyanins, vitamin E, } \\
\text { flavonoids }\end{array}$ \\
\hline Laportea aestuans (L) Chew. & Extracts from fresh leaves & Essential oils \\
\hline $\begin{array}{l}\text { Leonotis nepetifolia }(\mathrm{L}) \\
\mathrm{R} \text {. Br. }\end{array}$ & Extracts from fresh leaves & $\begin{array}{l}\text { Flavonoids, terpenes, } \\
\text { essential oils, coumarins }\end{array}$ \\
\hline $\begin{array}{l}\text { Maximiliana maripa } \\
\text { (Correa) Drude. }\end{array}$ & Seed oil & $\begin{array}{l}\text { Vitamins A and E } \\
\text { compounds, fatty acids }\end{array}$ \\
\hline Morinda citrifolia $\mathrm{L}$. & $\begin{array}{l}\text { Extracts from fresh fruits, } \\
\text { seed oil }\end{array}$ & Flavonoids, fatty acids \\
\hline Moringa olifeira Lam. & Extracts from fresh leaves & Ben oil \\
\hline Orchid spp. & Seed extracts & Essential oils \\
\hline $\begin{array}{l}\text { Plectranthus amboinicus } \\
\text { Lour. }\end{array}$ & Extracts from fresh leaves & Essential oils \\
\hline Senna alata (L.) Roxb. & Extracts from fresh leaves & $\begin{array}{l}\text { Phenolic compounds, } \\
\text { essential oils }\end{array}$ \\
\hline Tamarindus indica $\mathrm{L}$. & $\begin{array}{l}\text { Extracts from fresh leaves, } \\
\text { seed extracts }\end{array}$ & $\begin{array}{l}\text { Polyphenols, flavonoids, } \\
\text { xyloglucan, fatty acids }\end{array}$ \\
\hline $\begin{array}{l}\text { Tripogandra serrulata } \\
\text { (Vahl.) Handlos }\end{array}$ & $\begin{array}{l}\text { Extracts from fresh leaves or } \\
\text { whole plant }\end{array}$ & Unknown \\
\hline
\end{tabular}

These applications may be supported by the moisturizing effects of the fatty acids [68] and the antioxidant properties of particularly the phenolic compounds and vitamin E [67].

\section{Bryophyllum pinnatum (Lam) Oken.}

Preparations from the mother-of-thousands B. pinnatum (Figure 7) are abundantly used as traditional astringent, anti-inflammatory, and antiseptic substances to treat burns, wounds, bruises, boils, and sores [69-71]. This may account for the inclusion of $B$. pinnatum constituents in a variety of cosmetics and cosmeceuticals such as products for facial cleansing, creams for fighting wrinkles, ointments for treating acne, rashes and warts, anti-dandruff shampoos, hair growth-promoting tonics, anti-ageing creams, and skin regenerationpromoting formulas $[72,73]$. Further support for these applications comes from the beneficial effects of fumaric acid in B. pinnatum leaves against skin conditions such as psoriasis [74], and the cicatrizant and amphiphatic and antimicrobial properties of the saponins in various parts of the plant that may promote woud healing [75].

\section{Carapa guianensis Aubl.}

The bark of the crabwood C. guianensis contains alkaloids such as carapina which possess antipyretic properties [76]. Concotions prepared from the leaves and fruits are traditionally used to relieve itching and treat intestinal worms [76]. The seed oil from the plant is also known as carap oil or crab oil and contains limonoids with, among others, anti-inflammatory, anti-allergic, antiparasitic, antimicrobial, and wound healing-promoting properties [76,77-79]. For these reasons, carap oil is commonly included in skin care preparations, skinregenerating products, anti-ageing treatments, anti-cellulite creams, and anti-inflammatory acne medications [80]. The oil also contains a number of unsaturated fatty acids such as palmitic acid, oleic acid, and linoleic acid which make it useful as an ingredient of soaps, body washes, skin conditioners, facial moisturizers, facial masks, eye creams, as well as shampoos and hair conditioners $[81,82]$.

\section{Cocos nucifera $\mathrm{L}$.}

Parts of the coconut tree C. nucifera are traditionally used for treating a variety of diseases. For instance, a tea from the husk fibers is used in Brazil against diarrhea [83] and in Haiti against amenorrhea [84], a tea from the roots would treat diarrhea and stomach pains in Papua New Guinea [85], while coconut oil would prevent hair loss and promote wound healing according to Fijan and Indonesian beliefs [86]. These actions may be associated with the presence of phenols, tannins, leucoanthocyanidins, flavonoids, triterpenes, steroids, alkaloids, triterpenes, saponins, and condensed tannins in several parts of the plant [87], as well as that of vitamin E and a number of fatty acids in coconut oil [88]. For these reasons, coconut oil is an important base ingredient of shower gels, shampoos and hair conditions, moisturizers, emollients, nourishing agents, body butters, fragrances, sunscreens, formulations to prevent drying of the skin, anti-redness agents, antiageing agents, and remedies for skin infections [89].

\section{Copaifera guyanensis Desf.}

The medicinal properties of the oil from the copaiba tree $C$. guyanensis (Figure 8) were already known by American Indians, who observed that injured animals rubbed themselves on the tree's trunk to heal their wounds $[90,91]$. Copaiba oil is obtained by tapping the tree's trunk and was traditionally used against inflammations, infections, malignancies, to stimulate wound healing, and to treat skin diseases $[92,93]$. The biologically active substances of copaiba oils are sesquiterpenes such as caryophyllene and diterpenes such as copalic acid and kaurenoic acid [92,93]. These compounds display

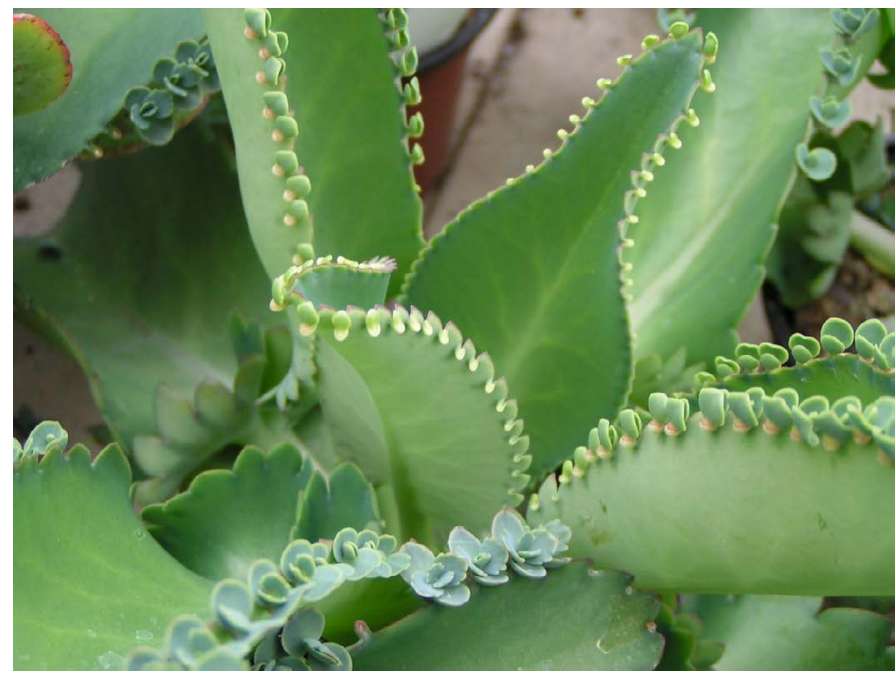

Figure 7. The mother-of-thousands Bryophyllum pinnatum (Lam) Oken. (Crassulaceae) (from https://goo.gl/images/fbgqpR) 


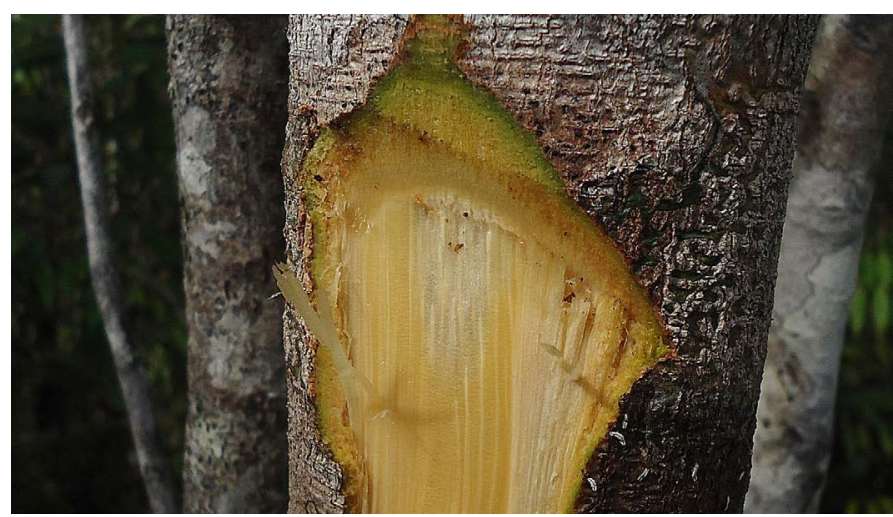

Figure 8. Harvesting copaiba oil from the trunk of Copaifera guyanensis Desf. (Fabaceae) (from https://goo.gl/images/ib4aaL).

substantial anti-inflammatory and antimicrobial effects including activity against Staphylococcus aureus (Staphylococcaceae) [92,94,95] which is a common cause of skin infections. For these reasons, copaiba oils are extensively used by the cosmetic industry in anti-acne creams, formulations for treating stretch masks and scars, as well as shampoos, capillary lotions, soaps, and bathing foams [96].

\section{Cucumis sativus $\mathrm{L}$.}

The fruits of the cucumber plant $C$. sativus consist for more than $90 \%$ of water [97], and contain, among others, vitamin K, B vitamins, as well as vitamin $\mathrm{C}$ and other antioxidants such as $\beta$-carotene, flavonoids, and phenolic compounds $[98,99]$. The high water contents is considered beneficial to the skin $[97,100]$, while the antioxidants may protect the skin from the effects of ageing [101,102]. For these reasons, C. sativus fruits, fruit extracts, fruit water, fruit juice, and seed extracts are abundantly used as skin-conditioning agents and included in numerous cosmetic formulations [97,100,103]. A few are foundations, facial and eye makeup, face and neck products, cleansing products, skin-hydrating products, bath foams, soaps and detergents, facial peel-off masks, hair care products, nail care products, body and hand lotions, and products for skin rejuvenation $[97,100,103]$.

\section{Cymbopogon citratus (Dc) Stapf.}

Preparations from the lemongrass C. citratus leaves are popularly used, among others, as antimicrobials, antiprotozoals, antiinflammatory compounds, antidyspeptics, spasmolytics, antipyretics, diuretics, and insect repellents [104,105]. These applications are supported by the antibacterial, antifungal, antiparasitic, antidiarrheal, anti-inflammatory, cytoprotective, and antioxidant effects noted in preclinical models [106]. At least part of these observations may be attributable to the presence in the leaves of flavonoids and phenolic compounds as well as essential oils containing citral, geraniol, citronellol, citronella, and myrcene $[107,108]$. The pleasantly smelling essential oils are widely included as fragrances in perfumes, soaps, detergents, and creams [109]. Citral also serves as starting material for the synthesis of ionones for perfumes and cosmetics [107,109]. The byproducts from the distillation process that yields the oils are used for the production of skin care products such as lotions, creams, and facial cleansers $[107,109]$. These applications are primarily attributed to the meaningful antimicrobial properties of the oils [110].

\section{Eclipta prostata (L.) L.}

The main traditional indications for the false daisy E. prostrata are gastrointestinal complaints, liver ailments, respiratory tract disorders, fever, spleen enlargement, skin problems, cuts and wounds, microbial and parasitic infections, as well as hair loss and graying of hair [111]. The latter uses are supported by the addition of an ethanol extract of E. prostrata leaves to hair oils in Ayurveda [111] and the hair growthstimulatory effects of petroleum ether extracts of these parts of the plant in shaved laboratory rats $[112,113]$. These applications may be attributable, at least partially, to the presence in E. prostrata of, among others, coumestans such as wedelolactone; oleanane-type glycosides such as eclalbasaponins; and triterpenes such as amyrins, precursors of ursolic acid and oleanolic acid [114]. These compounds possess, among others, antibacterial, anti-inflammatory, antieczema, as well as antioxidant properties [115-118] which may confer protection from damage caused by ultraviolet irradiation [114]. For these resons, E. prostrata extracts and oils are included in many hair growth promoters, products to prevent hair loss, as well as skin-nourishing and antiageing agents [22].

\section{Euterpe oleracea Mart.}

The fruits of the açaí palm E. oleracea are in various parts of the world - particularly Brazil - processed into pulp for supply to food product manufacturers or retailers; sold as frozen pulp or juice; incorporated in beverages, smoothies, and other food products; and formulated as dietary supplements [119]. The popularity of these products is based on the remarkably high polyphenolic anthocyanin contents $[120,121]$ and the superior antioxidant qualities of the açai berry [122] which would provide a host of health benefits [123]. These claims, together with the relatively high levels of oleic and palmitic fatty acids in the oil extracted from açai berrries [124], have encouraged the production of a variety of açai-based cosmetics. The anthocyanins and phenolic compounds would treat and prevent skin damage and are included in, among others, skin regenerating and anti-ageing creams, anti-inflammatory products, and sunscreens $[125,126]$. The soothing and nourishing fatty acids would make it suitable for use in cosmetics as soaps, skin moisturizers shampoos, and hair conditioners $[125,126]$.

\section{Hibiscus sabdariffa L.}

Preparations from the calyces of the roselle H. sabdariffa (Figure 9) are used in many folk medicinal systems for treating a broad range of conditions such as microbial infections, cough and bronchitis, kidney

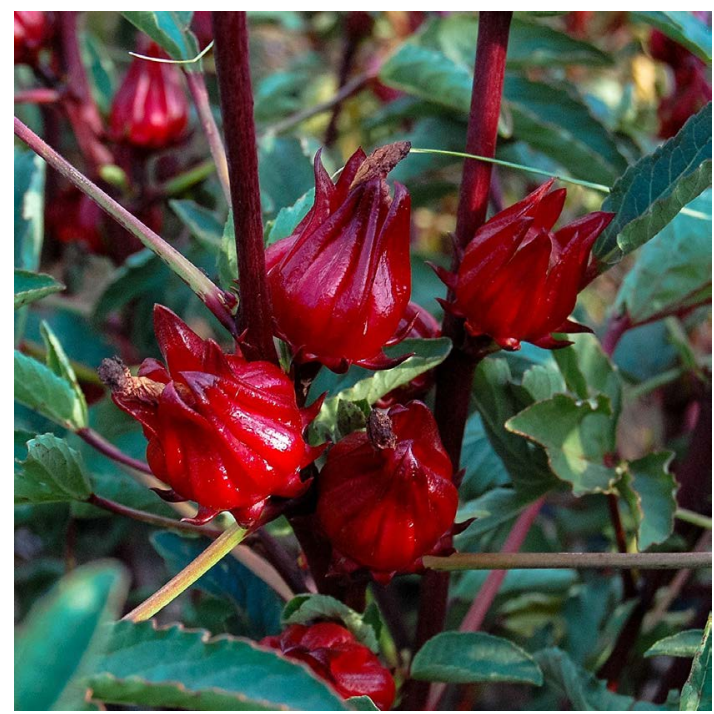

Figure 9. The roselle Hibiscus sabdariffa L. (Malvaceae) (from https://goo.gl/ images/75wRmG). 
problems, and gastrointestinal conditions [127]. These applications may be attributable, at least in part, to the presence in the plant of antioxidant anthocyanins [127,128] and vitamin E [127,129]; a number of flavonoids with notable antibacterial activity $[127,130]$; and the phenolic compound protocatechuic acid that exerted an antiinflammatory effect in laboratory animals [131]. For these reasons, extracts from $H$. sabdariffa calyces are commonly included in skin care products, skin-protecting agents, anti-ageing creams, and hair care products [132]. Notably, crude polysaccharides in $H$. sabdariffa flowers had a potent stimulatory effect on the proliferation of cultured keratinocytes [133].

\section{Laportea aestuans (L) Chew.}

Preparations from the West Indian wood nettle L. aestuans are traditionally used for treating many ailments including microbial and parasitic infections, minor eye infections, as well as syphilis and gonorrhea [134,135]. At least some of these applications may be attributable to the presence in the plant of bioactive substances with antimicrobial and antioxidant properties [136-138]. A few examples are the chrysen-2-ol derivative and methyl salicylate in the essential oils from the leaves which exhibited in vitro antimicrobial activity $[138,139]$. These observations suggest that substances from $L$. aestuans may be useful against cellular injury and ageing. As a result, extracts from this plant are widely used in massage oils, lotions, creams, ointments, lip balms, face masks, scrubs, facial toners, antidandruff shampoos and conditioners, as well as remedies for treating acne, eczema, blemishes from chicken pox and insect bites, and scarring from burns [136]. Some of these preparations may be scented with the essential oils from the plant [139].

\section{Leonotis nepetifolia (L) R. Br.}

The lion's ear L. nepetifolia (Figure 10) contains various bioactive constituents such as flavonoids, alkaloids, quinines, saponins, terpenoids and terpenes, coumarins, as well as essential oils [140,141]. These compounds are present at varying concentrations in the sepals, leaves, stems, roots, and flowers of the plant $[142,143]$ and possess meaningful free radical-scavenging, antibacterial, antiparasitic, insecticidal, and anti-inflammatory properties [141]. This may account for the broad traditional use of parts of L. nepetifolia in order to suppress allergy symptoms, counteract muscle spasms, calm agitation, relieve

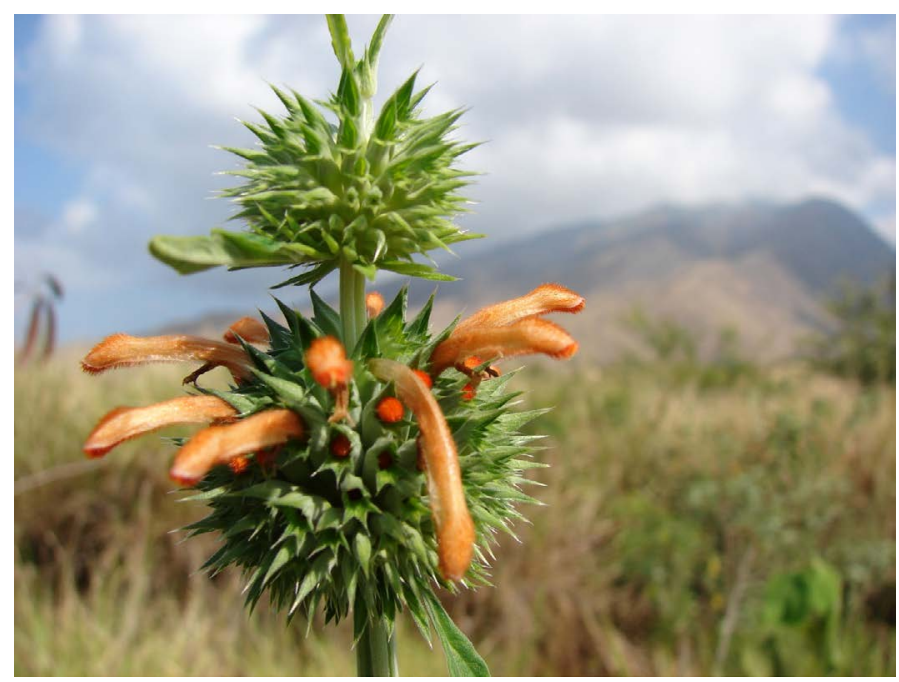

Figure 10. The lion's ear Leonotis nepetifolia (L) R. Br. (Lamiaceae) (from https://goo.gl/ images/rwb9QF). pain, heal burns, alleviate the symptoms of bronchial asthma, treat fever and colds, ease pain from arthritis, and fight malaria [141,144]. L. nepetifolia leaf extracts are also included in formulations for treating acne, skin rashes, and skin infections, as well as in skin-rejuvenating and -regenerating products $[145,146]$. The flavonoids have antioxidant activities while the essential oils have emollient as well as antibacterial properties $[145,146]$ and confer, together with the coumarins and diterpenes $[140,146]$ a pleasant fragrance to these products.

\section{Maximiliana maripa (Correa) Drude.}

The pulp and seed kernels of the fruits of the maripa palm $M$. maripa yield an edible oil that consists of, among others, $\alpha$-carotene, tocotrienols, tocopherols, phytosterols, glycolipids, and fatty acids [147149]. These compounds have emollient, antioxidant, and antimicrobial properties [150], which may explain the long traditional use of maripa oil for skin care, to prevent skin ageing, to stop alopecia and stimulate hair growth, to fight stretch marks, and to smoothen scarred skin [151152]. It is also used as a massage oil to bring relief in rheumatic parts of the body [152]. For these reasons, M. maripa oil is commonly included in soaps, moisturizers and other skin care products, rejuvenation and anti-ageing formulations, creams for treating acne, as well as shampoos and hair conditioners $[148,152]$.

\section{Morinda citrifolia $\mathbf{L}$.}

Preparations from the noni $M$. citrifolia are used for treating a long list of ailments ranging from wounds, sores, burns, sprains, and dislocations to diabetes mellitus, high blood pressure, AIDS, and malignant neoplasms [153-155]. More recently, clinical studies found that noni leaf extracts protected the skin from erythema caused by ultraviolet light [155], and that noni seed oil had meaningful antiinflammatory activity in acne [156]. As a result, a host of noni-based cosmetics and cosmeceuticals have been manufactured, including hand and facial soaps, shampoos and conditioners, foot and body lotions, body powders, deodorants, ointments for treating acne, formulations to fight wrinkles, as well as eye creams, rejuvenating face masks, moisturizers, and night creams to reduce signs of aging [155]. The antioxidant activity of flavonoids and the emollient properties of fatty acids in the fruits and leaves of the plant [153,154,157-159], and the anti-inflammatory action of ingredients in the seed oil $[156,159]$ may contribute to the beneficial effects of these products.

\section{Moringa oleifera Lam.}

M. olifeira is traditionally used to stimulate diuresis, to relieve spasms, for treating the symptoms of diabetes mellitus, as a cardiac stimulant, as an antimicrobial and antiparasitic substance, and for treating many other conditons [160]. The edible oil from the seeds is called ben oil because of its high contents of the fatty acid behenic acid $[161,162]$. Ben oil is included in moisturizing and emollient oils for therapeutic massages and is used as a carrier oil for aromatherapy $[161,162]$. Ben oil as well as $M$. olifeira leaf extracts also contain substantial quantities of vitamins $\mathrm{A}, \mathrm{C}$, and $\mathrm{E}$ as well as $\beta$-carotene and polyphenols which may possess anti-inflammatory and anti-oxidant properties $[163,164]$. For these reasons, both the seed oil and leaf extracts are included in creams, lotions, balms, soaps, scrubs, body oils, moisturizers, hair care products, and sunscreens [161,162,165-167]. Ben oil is also used as a base for perfumes because of the capacity of behenic acid to neutralize malodors [167].

\section{Orchidaceae}

Members of the orchid family Orchidaceae (Figure 11) have a long tradional use in various medicinal systems [168]. This holds 


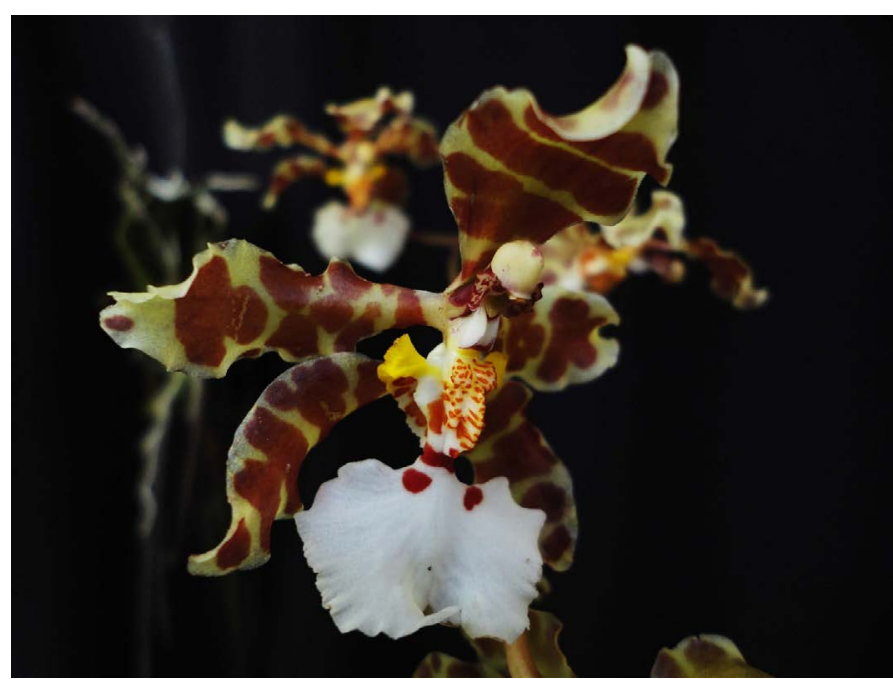

Figure 11. The tiger orchid Oncidium jonesianum (Orchidaceae) (from https://goo.gl/ images $/ \mathrm{hLYpNu}$ ).

particularly true for traditional Chinese medicine that used certain species for treating a variety of diseases ranging from urinary tract disorders to diabetes mellitus, hypertension, and cancer [169]. The apparent therapeutic efficacy of these preparations may be attributable to alkaloids with medicinal properties [169], but this remains to be established. At least one orchid species - the vanilla orchid Vanilla planifolia Jacks. ex Andrews - is renowned as a flavoring in baking, for perfume manufacture, and in aromatherapy [170]. Extracts from other orchid species are also incorporated in a variety of cosmetics and cosmeceuticals. Some contain phenolics and flavonoids with meaningful antioxidant and anti-inflammatory activity and are important ingredients of anti-ageing creams [168,171-173]. Others contain substances with a high water-binding capacity and/or constituents that increase stratum corneum hydration, and have become essential ingredients of skin moisturizers and emollients [172]. Orchid flowers are also an important source of fragrances for toiletries, skin care products, bathing products, and hair care products [174]. In many cases, their scent is analyzed by perfumers to identify potentially novel bouquets [175].

\section{Plectranthus amboinicus Lour.}

Preparations from Plectranthus species are traditionally used for treating a broad range of conditions including gastrointestinal, respiratory, and genitourinary ailments as well as infections and fever $[176,177]$. Extracts from the leaves and the strongly oreganolike scented essential oils from this plant genus are also used against a variety of skin problems including burns, wounds, sores, insect bites, parasitic infections, and allergies [178,179], as well as an antiseptic dressing for wounds [180]. Some of these traditional uses may be explained by the presence in these plant species of monoterpenes and sesquiterpenes diterpenoids and phenolic compounds with, among others, antimicrobial, anti-inflammatory, and antioxidant properties $[181,182]$. For these reasons, extracts and essential oils from the leaves of the thick leaf thyme P. amboinicus are included in soaps, moisturizers, skin cleansers; anti-acne formulations; anti-wrinkle, skin-rejuvenating, and anti-ageing night creams; and ointments for treating insect bites and itchy skin $[176,177]$.

\section{Senna alata (L.) Roxb.}

The leaves, seeds, fruits, bark, and roots of the candle bush $S$. alata (Figure 12) contain a number of bioactive compounds such as anthraquinones, phytosterols, tannins, alkaloids, flavonoids, terpenes, phenolic compounds, and essential oils [183,184]. Some of these compounds have been associated with the laxative and purgative properties of $S$. alata preparations [183,184]; their efficacy against scabies and ringworm infections as well as fungal infections of the skin such as Pityriasis versicolor [185]; their antibacterial effects [186], their anti-inflammatory activity [187], and their capacity to reduce ultraviolet irradiation-induced skin damage [188]. For these reasons, $S$. alata leaf extracts are included in many cosmetics and dermatological skin care products such as soaps, sunscreens, anti-ageing agents, and skin-repairing agents [189].

\section{Tamarindus indica $\mathrm{L}$.}

Preparations from T. indica are traditionally used fror treating a broad range of ailments such as abdominal ailments, parasitic infestation, fever, malaria, and respiratory problems [190]. These properties may be attributable to the presence in the plant of various phytochemicals with, among others, antibacterial, antifungal, antiviral, antiparasitic, anti-inflammatory, and antioxidant properties [191,192,193,194]. T. indica leaves contain various polyphenols and flavonoids with wound healing-stimulating properties [195,196], the seeds contain the hemicellulose xyloglucan which can protect the skin from the damaging effects of ultraviolet radiation [197], and the seed oil contains abundant amounts of linoleic acid and oleic acid [194]. For these reasons, T. indica preparations are included in regenerating and anti-ageing night creams, sunscreens, ointments for treating minor skin rashes, as well as serums, gels, facial toners, moisturizers, face masks, lip balms, body lotions, and soaps [198].

\section{Tripogandra serrulata (Vahl) Handlos}

Preparations from the whole plant or the leaves of the pink trinity T. serrulata - ether alone or together with parts from other plants - are highly valued in various South American and Caribbean countries. T. serrulata-containing remedies are traditionally used against biliousness and kidney disorders, as a purgative, and to cleanse the uterus and the oviducts [199], but also for treating traumas and wounds [200,201] along with inflammations and fractures [202]. In addition, the macerated leaves are used to prevent hair loss and promote hair growth [44,203] and are applied to the face to stimulate beard growth [199]. For these reasons, T. serrulata leaf extracts are included in a number of hair care products [200,203], despite the lack of comprehensive data on the phytochemical information about the extracts.

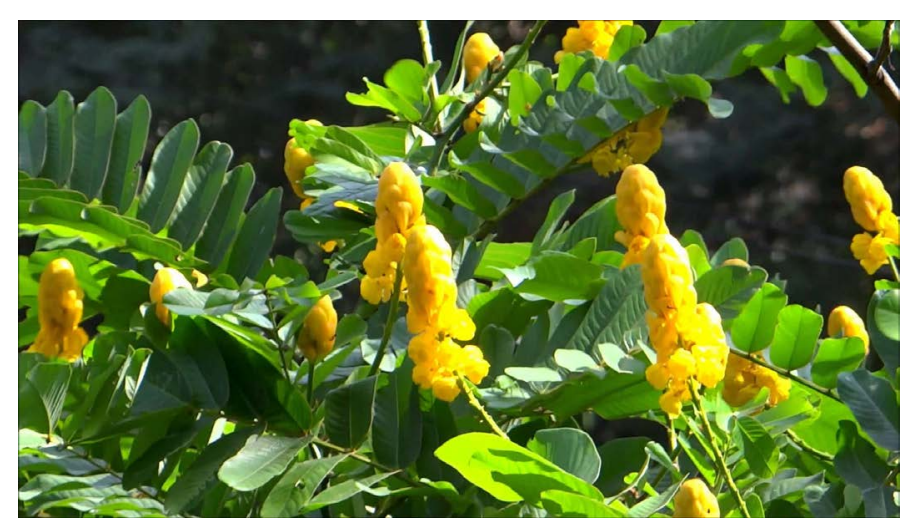

Figure 12. The candle bush Senna alata (L.) Roxb. (Fabaceae) (from https://goo.gl/images/ woZP5q). 


\section{Future prospects}

This paper has addressed the beauty industry in Suriname, the commonly used plants for manufacturing these products in the country, as well as the scientific rationale for using these plants. So far, only a relative handful of Suriname's abundant plant biodiversity encompassing an estimated 5,000 higher plants is used for cosmetic and cosmeceutical purposes. Furthermore, these plants are mainly collected (and sometimes cultivated) in the accessible parts of the country's hinterland rather than in the less approachable and ill-explored regions in the remote south of the country [49]. Thus, it is possible that Suriname is in the possession of a largely untapped reservoir for the development of the currently much-sought-after herbal cosmetics and cosmeceuticals.

This holds the prevision of identifying numerous plant products for developing novel naturally-derived beauty products. For instance, the orange-red wax from the seeds of the annatto or lipstick plant Bixa orellana L. (Bixaceae) (Figure 13) has a long use of facial and body ornamentation by the Indigenous peoples of the Amazon basin [204] and may not only be included in lipsticks but also in rouge powders and cream blushes, eye shadows, and nail polishes. The young shoots of the sour orange Citrus $x$ aurantium L., 1753 (Rutaceae) are commonly chewed on by particularly older Creole women to freshen their breath, and the essential oil in these parts of the plant may be included in mouth washes, soaps, skin care products, and deoderants. And the essential oil from the seeds of the tonka bean tree Dipteryx odorata (Aubl.) Willd. (Fabaceae) is widely used in the perfume industry because of its high contents of coumarins with very pleasant odors, but may also be incorporated into hair and skin care products because of the folkloristic use of tonka bean oil to fortify the scalp and improve hair growth [205].

However, important conditions to take advantage of these opportunities are the creation of a favorable technological environment, the reinforcement of good manufacturing practices, and the implementation of successful marketing strategies. Furthermore, information about the pharmacologically active ingredient(s) and mechanism(s) of action of cosmetics and cosmeceuticals should be mandatory, even though neither of these products has to undergo the thorough and lengthy evaluations required for pharmaceutical products. Unfortunately, this is by no means always the case.

For instance, despite some supporting evidence for wound healingpromoting activity of A. vera, "there is a need for high-level evidence and

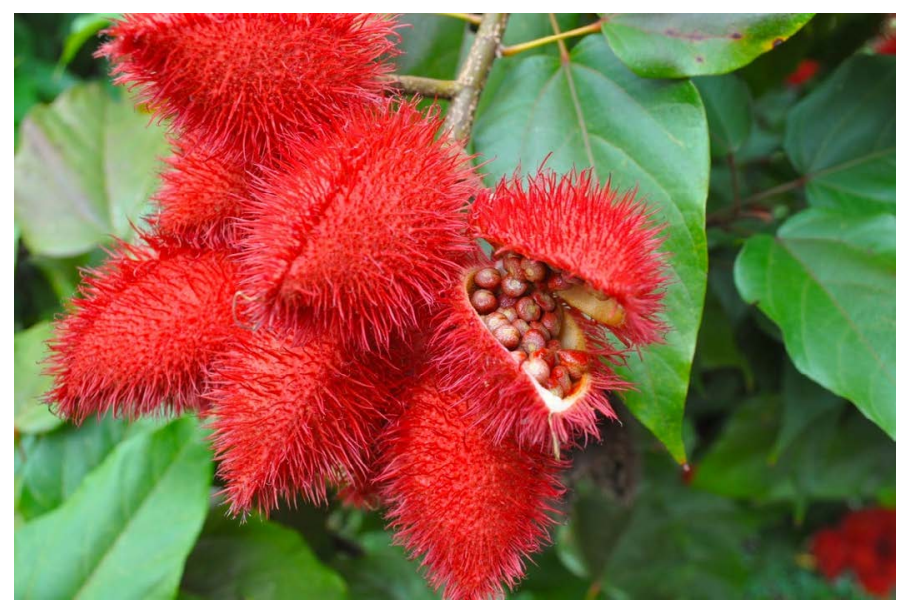

Figure 13. Seeds of the annatto Bixa orellana L. (Bixaceae) (from https://goo.gl/images/ w2V5BE). further large, randomized control trials to support the use of A.veraderived products as topical agents or incorporated within dressings for the treatment of skin lesions" [206]. Products from E. olearacea are among the most popular functional foods and cosmetics/cosmeceuticals throughout the world, but the scientific evidence to support their many claims of health benefits is insufficient [121]. And although tonics for general health from freshly squeezed noni fruits, 'power' and energy drinks that contain noni fruit juice, and powders from dried noni fruits or leaves formulated as capsules or pills are in high demand, most of the claims of M. citrifolia are not supported by hard scientific evidence [154].

Clearly, further development of the herbal cosmetics/cosmeceuticals industry including that in Suriname requires close attention to these aspects. Evidently, such information is not only of benefit to the consumer but also supports the reliability of the manutacturer.

\section{References}

1. Wanjari N, Waghmare J (2015). A review on latest trend of cosmetics-cosmeceuticals. Int J Pharma Res Rev 45: 45-51.

2. Joshi LS, Pawar HA (2015) Herbal cosmetics and cosmeceuticals: an overview. Nat Prod Chem Res 3: 1-10

3. Watts I (2010) The pigments from Pinnacle Point Cave 13B, Western Cape, South Africa. J Hum Evol 59: 392-411. [Crossref]

4. Power C (2010) Cosmetics, identity and consciousness.J Conscious Stud 17: 73-94.

5. Scott DA (2016) A review of ancient Egyptian pigments and cosmetics. Stud Conserv 61: 185-202.

6. Murube J (2013) Ocular cosmetics in ancient times. Ocul Surf 11: 2-7. [Crossref]

7. Hetta MH (2016) Phytocosmetics in Africa. Int J Phytocosm Nat Ingred 3:

8. Blanco-Dávila F (2000) Beauty and the body: the origins of cosmetics. Plast Reconstr Surg 105: 1196-1204. [Crossref]

9. Watson P (2012) Cosmetics, Greece and Rome. The Encyclopedia of Ancient History.

10. Parish LC, Crissey JT (1988) Cosmetics: a historical review. Clin Dermatol 6: 1-4. [Crossref]

11. Naidoo L, Khoza N, Dlova NC (2016) A fairer face, a fairer tomorrow? A review of skin lighteners. Cosmetics 3: 1-10.

12. Hsieh S, Maranda EL, Salih T, Nguyen A, Jimenez J (2016) The quest for the ultimate skin-lightening agent. JAMA Dermatol 152: 372. [Crossref]

13. Stutesman D (2016) The silent screen, 1895-1927. pp. 21-46. In McLean A, ed. Costume, Makeup, and Hair. Rutgers University Press, New Brunswick, USA.

14. Hawkins JW, Doona ME, Higgins LP (1997) American women in the 1920s. Reflections 23: 20-21. [Crossref]

15. Jones G (2011) Globalization and beauty: a historical and firm perspective. Euramerica 41: 885-916.

16. Murnen SK, Seabrook R (2012) Feminist perspectives on body image and physical appearance. pp. 438-443. In: Cash TF, ed. Encyclopedia of Body Image and Human Appearance, Vol 1. Academic Press, San Diego, USA.

17. Schlessinger J (2007) Skin care for men and its marketing. Dermatol Ther 20: 452-456. [Crossref]

18. L’Oréal Finance (2015) Annual Reports.

19. Ribeiro AS, Estanqueiro M, Oliveira MB, Lobo JMS (2015) Main benefits and applicability of plant extracts in skin care products. Cosmetics 2: 48-65.

20. Chaudhri SK, Jain NK (2009) History of cosmetics. Asian J Pharm 3:164-167.

21. Atanasov AG, Waltenberger B, Pferschy Wenzig EM, Linder T, Wawrosch C, et al (2015) Discovery and resupply of pharmacologically active plant-derived natural products: a review. Biotechnol Adv 33: 1582-1614. [Crossref]

22. Kapoor VP (2005) Herbal cosmetics for skin and hair care. Nat Prod Radiance 4: 306314

23. Barbulova A, Colucci G, Apone F (2015) New trends in cosmetics: by-products of plant origin and their potential use as cosmetic active ingredients. Cosmetics 2: 82-92. 
24. General Bureau of Statistics/Census office (2013) Suriname in numbers 2013/05. Results of the eight-general census of Suriname, Demographic and social characteristics and migration. General Bureau of Statistics, Paramaribo (Suriname).

25. Hammond DS (2005) Tropical rainforests of the Guiana Shield. CABI Publishing, Wallingford, UK.

26. General Bureau of Statistics (2014) Suriname in numbers 303-2014-04. Basic indicators. General Bureau of Statistics, Paramaribo (Suriname).

27. World Data Atlas (2016) Suriname - Data and statistics.

28. Helman A (1977) Cultural mosaic of Suriname. A contribution to mutual understanding. De Walburg Pers, Zutphen (The Netherlands).

29. Mans DRA, Ganga D, Karto J (2017) Meeting of the minds: traditional herbal medicine in multiethnic Suriname. pp. 111-132. In: El-Shemy H, ed. Aromatic and Medicinal Plants - Back to Nature. InTech, Rijeka, Croatia.

30. Ministry of Health (2008) Report of the Director of Health 2005-2007. Ministry of Health Republic of Suriname, Paramaribo (Suriname).

31. Herndon CN, Uiterloo M, Uremaru A, Plotkin MJ, Emanuels-Smith G, et al. (2009) Disease concepts and treatment by tribal healers of an Amazonian forest culture. $J$ Ethnobiol Ethnomed 5: 27. [Crossref]

32. Joseph B, Jini D (2013) Antidiabetic effects of Momordica charantia (bitter melon) and its medicinal potency. Asian Pac J Trop Dis 3: 93-102.

33. Onwuanibe RC (1979) The philosophy of African medicinal practice. J Opin 9: 25-28.

34. Wooding CJ (1979) Traditional healing and medicine in Winti: a sociological interpretation. J Opin 9: 35-40.

35. Dragtenstein F (2004) Loyalty to Whites. Quassie van Nieuw Timotibo, strife and struggle in the 18th century in Suriname. NiNsee/KIT Publishers, Amsterdam (The Netherlands)

36. Alzohairy MA (2016) Therapeutics role of Azadirachta indica (neem) and their active constituents in diseases prevention and treatment. Evid Based Complement Alternat Med 2016: 7382506. [Crossref]

37. Kumar VS, Navaratnam V (2013) Neem (Azadirachta indica): prehistory to contemporary medicinal uses to humankind. Asian Pac J Trop Biomed 3: 505-514. [Crossref]

38. Hossaina MA, Al-Toubia WAS, Welia AM, Al-Riyamia QA, Al-Sabahiba JN (2013) Identification and characterization of chemical compounds indifferent crude extracts from leaves of Omani neem. J Taibah Univ Sci 7: 181-188.

39. Tjong Ayong G (1989) The use of medicinal plants by the Javanese in Suriname. Instituut voor de Opleiding van Leraren, Paramaribo (Suriname).

40. Al-Adhroey AH, Nor ZM, Al-Mekhlafi HM, Mahmud R (2010) Median lethal dose, antimalarial activity, phytochemical screening and radical scavenging of methanolic Languas galanga rhizome extract. Molecules 15: 8366-8376.

41. Block KI, Mead MN (2003) Immune system effects of echinacea, ginseng, and astragalus: a review. Integr Cancer Ther 2: 247-267. [Crossref]

42. Matkovic Z, Zivkovic V, Korica M, Plavec D, Pecanic S, et al. (2010) Efficacy and safety of Astragalus membranaceus in the treatment of patients with seasonal allergic rhinitis. Phytother Res 24: 175-181. [Crossref]

43. Harley CB, Liu W, Blasco M, Vera E, Andrews WH, et al. (2011) A natural product telomerase activator as part of a health maintenance program. Rejuvenation Res 14 : 45-56. [Crossref]

44. Van Andel TR, Ruysschaert S (2011) Medicinal and ritual plants of Suriname. KIT Publishers, Amsterdam (The Netherlands).

45. Van't Klooster C, van Andel T, Reis R (2016) Patterns in medicinal plant knowledge and use in a Maroon village in Suriname. J Ethnopharmacol 189: 319-330. [Crossref]

46. Raghoenandan UPD (1994) An ethnobotanical investigation among Hindustanis in Suriname. Anton de Kom Universiteit van Suriname, Paramaribo (Suriname).

47. Playfair M, Esseboom M, Zschuschen E (2011) Marktverkenning van potentiële non-timber forest products en niet-industriële houtproducten voor de Marchallkreek community. CELOS, Paramaribo (Suriname).

48. Chamber of Commerce and Industry, Suriname. Accessed at: http://www. surinamechamber.com/index.php/welcome/index/business_directory.

49. Grant A (2017) Planten die gebruikt worden voor gezichtsbehandelingen. Een onderzoek onder de natuurproducten in Suriname. Instituut voor de Opleiding van Leraren, Paramaribo (Suriname).
50. Pazyar N, Yaghoobi R, Ghassemi MR, Kazerouni A, Rafeie E, et al. (2013) Jojoba in dermatology: a succinct review. G Ital Dermatol Venereol 148: 687-691. [Crossref]

51. Honfo FG, Akissoe N, Linnemann AR, Soumanou M, Van Boekel MA (2014) Nutritional composition of shea products and chemical properties of shea butter: a review. Crit Rev Food Sci Nutr 54: 673-686. [Crossref]

52. Garavaglia J, Markoski MM, Oliveira A, Marcadenti A (2016) Grape seed oil compounds: biological and chemical actions for health. Nutr Metab Insights 9: 59-64. [Crossref]

53. Manvitha K, Bidya B (2014) Aloe vera: a wonder plant its history, cultivation and medicinal uses. J Pharmacogn Phytochem 2: 85-88.

54. Mahor G, Ali SA (2016) Recent update on the medicinal properties and use of Aloe vera in the treatment of various ailments. Biosci Biotech Res Comm 9: 273-288.

55. Hamman JH (2008) Composition and applications of Aloe vera leaf gel. Molecules 13: 1599-1616. [Crossref]

56. Moghaddasi SM, Verma SK (2011) Aloe vera their chemicals composition and applications: a review. Int J Biol Med Res 2: 466-471.

57. Eshun K, He Q (2004) Aloe vera: a valuable ingredient for the food, pharmaceutical and cosmetic industries--a review. Crit Rev Food Sci Nutr 44: 91-96. [Crossref]

58. Qadir MI (2009) Medicinal and cosmetological importance of Aloe vera. Int J Nat Ther 2: 21-26.

59. Periasamy G, Kassa S, Sintayehu B, Mebrahtom Glibanos M, Geremedhin G, et al (2014) Cosmetic use of Aloe vera - a review. World J Pharm Pharm Sci 3: 342-458.

60. Galeane MC, Martins CHG, Massuco J, Bauab TM, Sacramento LVS (2017) Phytochemical screening of Azadirachta indica A. Juss for antimicrobial activity. Afr J Microbiol Res 11: 117-122.

61. Hashmat I, Azad H, Ahmed A (2012) Neem (Azadirachta indica A. Juss) - A nature's drugstore: an overview. International Research Journal of Biological Sciences 1: 7679.

62. Djibril D, Mamadou F, Gérard V, Geuye MDC, Oumar S, et al. (2015) Physical characteristics, chemical composition and distribution of constituents of the neem seeds (Azadirachta indica A. Juss) collected in Senegal. Res J Chem Sci 5: 52-58.

63. Mak-Mensah EE, Firempong CK (2011) Chemical characteristics of toilet soap prepared from neem (Azadirachta indica A. Juss) seed oil. Asian J Plant Sci Res 1: 1-7.

64. Yang J (2009) Brazil nuts and associated health benefits: a review. LWT Food Sci Technol 42: 1573-1580.

65. Chunhieng T1, Pétritis K, Elfakir C, Brochier J, Goli T, et al. (2004) Study of selenium distribution in the protein fractions of the Brazil nut, Bertholletia excelsa. J Agric Food Chem 52: 4318-4322. [Crossref]

66. Chunhieng T, Hafidi A, Pioch D, Brochier J, Montet D (2008) Detailed study of Brazil nut (Bertholletia excelsa) oil microcompounds: phospholipids, tocopherols and sterols. J Braz Chem Soc 19: 1374-1380.

67. John JA, Shahidi F (2010) Phenolic compounds and antioxidant activity of Brazil nut (Bertholletia excelsa). J Funct Foods 2: 196-209.

68. Kluczkovski AM, Martins M, Mundim SM, Simões RH, Nascimento KS, et al. (2015) Properties of Brazil nuts: a review. Afr J Biotechnol 14: 642-648.

69. Afzal M, Kazmi I, Khan R, Singh R, Chauhan M, Bisht T, Anwar F (2012) Bryophyllum pinnatum: a review. Int J Res Biol Sci 2: 143-149.

70. Dey A, Gupta B, De JN (2012) Traditional phytotherapy against skin diseases and in wound healing of the tribes of Purulia district, West Bengal, India. J Med Plants Res 6: $4825-4835$.

71. Nagaratna A, Hegde PL (2015) A comprehensive review on Parnabeeja [Bryophyllum pinnatum (Lam.) Oken]. J Med Plants Stud 3: 166-171.

72. El Abdellaoui S, Destandau E, Toribio A, Elfakir C, Lafosse M, Renimel I, André P, Cancellieri P, Landemarre L (2010) Bioactive molecules in Kalanchoe pinnata leaves: extraction, purification, and identification. Anal Bioanal Chem 398: 1329-1338.

73. Akpuaka MU, Ezem SN (2011) Preliminary phytochemical screening of some Nigerian dermatological plants. J Basic Phys Res 2: 1-5.

74. Amenta R, Camarda L, Di Stefano V, Lentini F, Venza F (2000) Traditional medicine as a source of new therapeutic agents against psoriasis. Fitoterapia 71 (Suppl 1): S13-20.

75. Kaur N, Bains R, Niazi J (2014) A review on Bryophyllam pinnatum - A medicinal herb. J Med Pharm Innov 1: 13-19. 
76. Henriques Md, Penido C1 (2014) The therapeutic properties of Carapa guianensis. Curr Pharm Des 20: 850-856. [Crossref]

77. Nayak B, Kanhai J, Milne D, Swanston W, Mayers S, et al. (2010) Investigation of the wound healing activity of Carapa guianensis L. (Meliaceae) bark extract in rats using excision, incision, and dead space wound models. J Med Food 13: 1141-1146.

78. Miranda Júnior RN1, Dolabela MF, da Silva MN, Póvoa MM, Maia JG (2012) Antiplasmodial activity of the andiroba (Carapa guianensis Aubl., Meliaceae) oil and its limonoid-rich fraction. J Ethnopharmacol 142: 679-683. [Crossref]

79. Pereira TB, Rocha E, Silva LF, Amorim RC, Melo MR, et al. (2014) In vitro and in vivo anti-malarial activity of limonoids isolated from the residual seed biomass from Carapa guianensis (andiroba) oil production. Malar J 13: 1-5.

80. Letawe C, Boone M, Pierard GE (1998) Digital image analysis of the effect of topically applied linoleic acid on acne microcomedones. Clin Exp Dermat 23: 56-58.

81. Campos V, Pompei R, Ferreira C (2007) Clinical study of a cosmetic cream to reduce dark circles under the eyes. $J$ Am Acad Dermatol 56 (Suppl 2): AB97.

82. Cabral EC, da Cruz GF, Simas RC, Sanvido GB, Gonçalves LDV, et al. (2013) Typification and quality control of the andiroba (Carapa guianensis) oil via mass spectrometry fingerprinting. Anal Methods 5: 1385-1391.

83. Esquenazi D, Wigg MD, Miranda MM, Rodrigues HM, Tostes JB, et al. (2002) Antimicrobial and antiviral activities of polyphenolics from Cocos nucifera Linn. (Palmae) husk fiber extract. Res Microbiol 153: 647-652. [Crossref]

84. Weniger B, Rouzier M, Daguilh R, Henrys D, Henrys JH, et al. (1986) Traditional medicine in the Central Plateau of Haiti. 2. Ethnopharmacologic inventory. Ethnopharmacol 17: 13-30. [Crossref]

85. Holdsworth D (1992) Medicinal plants of the Gazelle peninsula, New Britain Island, Papua New Guinea, Part I. Int J Pharmacogn 30: 185-190.

86. Sachs M, von Eichel J, Asskali F (2002) [Wound management with coconut oil in Indonesian folk medicine]. Chirurg 73: 387-392. [Crossref]

87. Lima EBC, Sousa CNS, Meneses LN, Ximenes NC, Santos Jr MA, et al. (2015) Cocos nucifera (L.) (Arecaceae): a phytochemical and pharmacological review. Braz J Med Biol Res 48: 953-964.

88. Da Fonseca AM, Marques DD, Lemos TLG, Aguiar GR, Bizerra AMC (2014) Fatty chemical composition and antioxidant activities of coconut oils (Cocos nucifera $\mathrm{L}$.). $J$ Med Plants Res 8: 1081-1085.

89. Gopala KAG, Raj G, Bhatnagar AS, Kumar PPK, Chandrashekar P (2010) Coconut oil: chemistry, production and its applications - a review. Indian Coconut 73: 15-27.

90. Veiga Jr VF, Pinto AC (2002) The Copaifera L. genus. Quim Nova 25: 273-286.

91. Veiga VF, Zunino L, Calixto JB, Patitucci ML, Pinto AC (2001) Phytochemical and antioedematogenic studies of commercial copaiba oils available in Brazil. Phytother Res 15: 476-480. [Crossref]

92. Veiga VF, Rosas EC, Carvalho MV, Henriques MGMO, Pinto AC (2007) Chemical composition and anti-inflammatory activity of copaiba oils from Copaifera cearensis Huber ex Ducke, Copaifera reticulata Ducke and Copaifera multijuga Hayne - A comparative study. J Ethnopharmacol 112: 248-254.

93. Lucas FdA, Kandrotas AL, Neto EN, de Siqueira CE, André GS, et al. (2017) Bromerschenkel I, Perri SHV. Copaiba oil in experimental wound healing in horses. Ciencia Rural 47: e20151292.

94. Leandro LM, Vargas Fde S, Barbosa PC, Neves JK, da Silva JA, et al. (2012) Chemistry and biological activities of terpenoids from copaiba (Copaifera spp.) oleoresins. Molecules 17: 3866-3889. [Crossref]

95. Santos AO, Ueda-Nakamura T, Dias Filho BP, Veiga VF Jr, Pinto AC, et al. (2008) Antimicrobial activity of Brazilian copaiba oils obtained from different species of the Copaifera genus. Mem Inst Oswaldo Cruz 103: 277-281.

96. Da Silva AG, Puziol PdF, Leitão RN, Gomes TR, Scherer R, et al. (2012) Application of the essential oil from copaiba (Copaifera langsdorffii Desf.) for acne vulgaris: a double-blind, placebo-controlled clinical trial. Altern Med Rev 17: 69-75.

97. Murad H, Nyc MA (2016) Evaluating the potential benefits of cucumbers for improved health and skin care. J Aging Res Clin Practice 5: 139-141.

98. Mukherjee PK, Nema NK, Maity N, Sarkar BK (2013) Phytochemical and therapeutic potential of cucumber. Fitoterapia 84: 227-236. [Crossref]

99. Rajasree RS, Sibi P, Francis F, William H (2016) Phytochemicals of Cucurbitaceae family - A review. Int $J$ Pharmacogn Phytochem Res 8: 113-123.
100. Akhtar N, Mehmood A, Khan BA, Mahmood T, Khan MHS, et al. (2011) Exploring cucumber extract for skin rejuvenation. Afr J Biotechnol 10: 1206-1216.

101. Ibrahim T, El-Hefnawy H, El-Hela A (2010) Antioxidant potential and phenolic acid content of certain cucurbitaceous plants cultivated in Egypt. Nat Prod Res 24: 15371545 .

102. Kumar D, Kumar S, Singh J, Narender, Rashmi, et al. (2010) Free radical scavenging and analgesic activities of Cucumis sativus L. fruit extract. J Young Pharm 2: 365368. [Crossref]

103. Maheshwari RK, Mohan L, Malhotra J, Updhuay B, Rani B (2014) Invigorating efficacy of Cucumis sativas for healthcare. Int J Chem Pharm Sci 2: 737-744.

104. Ekpenyong CE, Akpan EE, Daniel NE (2014) Phytochemical constituents, therapeutic applications and toxicological profile of Cymbopogon citratus Stapf (DC) leaf extract. J Pharmacogn Phytochem 3: 133-141.

105. 105 Olorunnisola SK, Asiyanbi HT, Hammed AM, Simsek S (2014) Biological properties of lemongrass: an overview. Int Food Res J 21: 455-462.

106. Shah G, Shri R, Panchal V, Sharma N, Singh B, et al. (2011) Scientific basis for the therapeutic use of Cymbopogon citratus, stapf (lemon grass). J Adv Pharm Technol Res 2: 3-8. [Crossref]

107. Ganjewala D (2009) Cymbopogon essential oils: chemical compositions and bioactivities. Int J Essen Oil Ther 3: 56-65.

108. Ekpenyong CE, Akpan E, Nyoh A (2015) Ethnopharmacology, phytochemistry, and biological activities of Cymbopogon citratus (DC.) Stapf extracts. Chin J Nat Med 13: 321-337.

109. Mosquera TT, Noriega RP, Cornejo JC, Pardo ML (2016) Biological activity of Cymbopogon citratus (DC) Stapf and its potential cosmetic activities. Int $J$ Phytocosm Nat Ingred 3: 07.

110. Pandey B (2017) Screening of antibacterial activity of essential oil of lemmon grass (Cymbopogon citratus). Indian J Sci Res 13: 29-31.

111. Saraswat VP, Verma S, Musale SV, Jaiswal ML (2015) A review on traditional and folklore uses, phyto-chemistry and pharmacology of Eclipta alba (L) Hassk. Int Ayurvedic Med J 3: 2462-2469.

112. Roy RK, Thakur M, Dixit VK (2008) Hair growth promoting activity of Eclipta alba in male albino rats. Arch Dermatol Res 300: 357-364. [Crossref]

113. Datta K, Singh AT, Mukherjee A, Bhat B, Ramesh B, et al. (2009) Eclipta alba extract with potential for hair growth promoting activity. J Ethnopharmacol 124: 450-456. [Crossref]

114. Chan CF, Huang WY, Guo HY, Wang BR (2014) Potent antioxidative and UVB protective effect of water extract of Eclipta prostrata L. ScientificWorldJournal 2014: 759039. [Crossref]

115. Uddin N, Rahman A, Ahmed NU, Rana S, Akter R, et al. (2010) Antioxidant, cytotoxic and antimicrobial properties of Eclipta alba ethanol extract. Int J Biol Med Res 1: 341-346.

116. Kumar SS, Sivakumar T, Chandrasekar MJ, Suresh B (2005) Evaluation of antiinflammatory activity of Eclipta alba in rats. Anc Sci Life 24: 112-118. [Crossref]

117. Kaur M, Chandola HM (2010) Role of rasayana in cure and prevention of recurrence of vicharchika (eczema). Ayu 31: 33-39. [Crossref]

118. Baldi A, Gupta R, Panwar MS (2011) Evaluation of in vitro antioxidant activity of Eclipta alba. Int J Pharm Biol Arch 2: 767-771.

119. De Santana AC, De Santana AL, De Santana AL (2017) Açaí pulp demand in the retail market of Belém, state of Para. Rev Bras Frutic 39: 1-10.

120. Bobbio FO, Druzian JI, Abrao PA, Bobbio PA, Fadelli S (2000) Identification and quantification of anthocyanins from the açai fruit (Euterpe oleracea) Mart. Ciênc Tecnol Aliment 20: 388-390.

121. Yamaguchi KK, Pereira LF, Lamarão CV, Lima ES, da Veiga-Junior VF (2015) Amazon acai: chemistry and biological activities: a review. Food Chem 179: 137151. [Crossref]

122. Kang J, Li Z, Wu T, Jensen GS, Schauss AG, et al. (2010) Anti-oxidant capacities of flavonoid compounds isolated from açai pulp (Euterpe oleracea Mart.). Food Chem 122: 610-617.

123. Portinho JA, Zimmermann LM, Bruck MR (2012) Beneficial effects of açai. Int $J$ Nutrol 5: 15-20. 
124. Schauss AG, Wu X, Prior R, Ou B, Patel D, et al. (2006) Phytochemical and nutrient composition of the freeze-dried amazonian palm berry Euterpe oleracea Mart. (açai). J Agric Food Chem 54: 8598-8603.

125. Hogan S, Chung H, Zhang L, Li J, Lee Y, et al. (2010) Antiproliferative and antioxidant properties of anthocyanin-rich extract from açai. Food Chem 118: 208214.

126. Daher CC, Fontes IS, Rodrigues RdO, Damasceno GAdB, Soares DdS, Aragão CFS Gomes APB, Ferrari M (2014) Development of O/W emulsions containing Euterpe oleracea extract and evaluation of photoprotective efficacy. Braz J Pharm Sci 50: $1-10$

127. Da-Costa-Rocha I, Bonnlaender B, Sievers H, Pischel I, Heinrich M (2014) Hibiscus sabdariffa L. - a phytochemical and pharmacological review. Food Chem 165: 424443. [Crossref]

128. Abou AAA, Abu SFM, Abou AEA (2011) Physicochemical properties of natura pigments (anthocyanin) extracted from Roselle calyces (Hibiscus subdariffa). J Am Sci 7: 445-456.

129. Mohamed R, Fernández J, Pineda M, Aguilar M (2007) Roselle (Hibiscus sabdariffa) seed oil is a rich source of gamma-tocopherol. J Food Sci 72: S207-211. [Crossref]

130. Mounnissamy VM, Kavimani S, Gunasegaran R (2002) Antibacterial activity of gossypetin isolated from Hibiscus sabdariffa. The Antiseptic 99: 81-82.

131. Liu CL, Wang JM, Chu CY, Cheng MT, Tseng TH (2002) In vivo protective effect of protocatechuic acid on tert-butyl hydroperoxide-induced rat hepatotoxicity. Food Chem Toxicol 40: 635-641.

132. Ismail A, Ikram EHK, Nazri HSM (2008) Roselle (Hibiscus sabdariffa L.) seeds nutritional composition protein quality and health benefits. Food 2: 1-16.

133. Brunold C, Deters A, Knoepfel-Sidler F, Hafner J, Müller B, et al. (2004) Polysaccharides from Hibiscus sabdariffa flowers stimulate proliferation and differentiation of human keratinocytes. Planta Medica 7: 370-373.

134. Lans C (2007) Comparison of plants used for skin and stomach problems in Trinidad and Tobago with Asian ethnomedicine. J Ethnobiol Ethnomed 3: 3. [Crossref]

135. Chukwuma EC, Soladoye MO, Feyisola RT (2015) Traditional medicine and the future of medicinal plants in Nigeria. J Med Plants Stud 3: 23-29.

136. Essiett UA, Edet NI, Bala DN (2011) Phytochemical and physicochemical analysis of the leaves of Laportea aestuans (Linn.) Chew and Laportea ovalifolia (Schumach.) Chew (male and female). Asian J Plant Sci Res 1: 35-42.

137. Oloyede GK, Ayanbadejo OE (2014) Phytochemical, toxicity, antimicrobial and antioxidant screening of extracts obtained from Laportea aestuans (Gaud). $J$ Med Sci 14: 51-59.

138. Okereke SC, Chukwudoruo CS, Nwaokezie CO (2017) Antioxidant enzyme activities and chemopreventive potentials of Laportea aestuans on urinary inflammatory markers using albino rats. J Med Plants Stud 5: 288-291.

139. Oloyede GK (2016) Toxicity, antimicrobial and antioxidant activities of methyl salicylate dominated essential oils of Laportea aestuans (Gaud). Arabian J Chem 9: S840-S845.

140. Imran S, Suradkar SS, Koche DK (2012) Phytochemical analysis of Leonotis nepetifolia (L.) R. Br., a wild medicinal plant of Lamiaceae. Biosci Discov 3: 197-199.

141. Mazimba O (2015) Leonotis leonurus: a herbal medicine review. J Pharmacogn Phytochem 3: 74-82.

142. Pedro LG, Barroso JG, Marques NT, Ascensao L, Paid MS, et al. (1991) Composition of the essential oil from sepals of Leonotis leonurus R. Br. J Essent Oil Res 3: 451-453.

143. Oyedeji OA, Ekundayo O, Koenig WA (1999) composition of the essential oil from the leaves of Leonotis nepetaefolia (L.). J Essent Oil Res 11: 716-718.

144. Niteshwar PR, Kumari H. (2012) Ethnomedicinal claims of Leonotis nepetifolia (L). R. Br. A Review. Int J Res Ayurveda Pharm 6: 783-785.

145. Oyedeji OA, Afolayan AJ (2005) Comparative study of the essential oil composition and antimicrobial activity of Leonotis leonurus and L. ocymifolia in the Eastern Cape, South Africa. S Afr J Bot 71: 114-116.

146. Udaya PNK, Bhuvaneswari S, Balamurugan A, Vaishnavi S, Sugunan S, et al. (2013). Studies on antibacterial, antioxidant, larvicidal, pesticidal activities and phytochemistry of Leonotis nepetifolia (Linn) R.Br. Int J Res Pharm Sci 4: 303-309.

147. Bereau D, Benjelloun-Mlayah B, Delmas M (2001). Maximiliana maripa Drude mesocarp and kernel oils: fatty acid and total tocopherol compositions. $J$ Am Oil Chem Soc 78: 213-214.
148. Dos Santos MFG, Alves RE, Roca M (2015) Carotenoid composition in oils obtained from Amazonian palms fruits. Grasas y Aceites 66: 086-093.

149. Fernández IM, Mozombite DMS, Santos RC, Melo Filho AA, Ribeiro RE, et al. (2016) Oil in inajá pulp (Maximiliana maripa): fatty acid profile and anticholinesterase activity. Orbital: Electron J Chem.

150. Dos Santos MdFG, Mamede RVS, Rufino MdSM, de Brito ES, Alves RE (2015) Amazonian native palm fruits as sources of antioxidant bioactive compounds. Antioxidants 4: 591-602.

151. Balslev H, Grandez C, Zambrana P, Møller AL, Hansen SL (2008) Palmas (Arecaceae) utiles en los alrededores de Iquitos, Amazonia Peruana. Rev Per Biol 15: 121-132.

152. Pereira AS, Alves HP, Souse CM, Costa GL (2013) Prospeção sobre o conhecimento de espécies amazônicas - inajá (Maximiliana maripa Aubl.) e bácaba (Oenocarpus bacaba Mart.). Revista Geintec 3, 110-122.

153. Kakad SL, Pise SS, Dhembare AJ (2015) Evaluation of phytochemical, antibacterial, antifungal activities of leaf extracts of Morinda citrifolia (Linn). Der Pharmacia Sinica 6: 9-12.

154. Assi RA, Darwis Y, Abdulbaqi IM, Khan AA, Vuanghao L, et al. (2017) Morinda citrifolia (noni): a comprehensive review on its industrial uses, pharmacological activities, and clinical trials. Arab J Chem 10: 691-707.

155. West BJ, Sabin RA (2012) Efficacy of a Morinda citrifolia-based skin care regimen. Curr Res J Biol Sci 4: 310-314.

156. Palu AK, West BJ, Jensen CJ (2012) Noni seed oil topical safety, efficacy, and potential mechanisms of action. J Cosm Dermatol Sci Appl 2: 74-78.

157. Krishnaiah D, Nithyanandam R, Sarbatly R (2012) Phytochemical constituents and activities of Morinda citrifolia L. pp. 127-150. In: Rao V, ed. Phytochemicals - A Global Perspective of Their Role in Nutrition and Health. InTech, Rijeka, Croatia.

158. Potterat O, Hamburger M (2007) Morinda citrifolia (noni) fruit--phytochemistry, pharmacology, safety. Planta Med 73: 191-199. [Crossref]

159. Levand O, Larson HO (1979) Some chemical constituents of Morinda citrifolia Planta Med 36: 186-187. [Crossref]

160. Taher MA, Nyeem MAB, Ahammed MM, Hossain MM, Islam MN (2017) Moringa oleifera (shajna): the wonderful indigenous medicinal plant. Asian J Med Biol Res 3: $20-30$.

161. Ashraf F, Gilani SR (2007) Fatty acids in Moringa oleifera oil. J Chem Soc Pakistan 29: 343-345.

162. Warra AA (2012) Production of soap from an Indigenous Moringa oleifera Lam Seed Oil. J Raw Mater Res 7: 23-30.

63. Ogbunugafor HA, Eneh FU, Ozumba AN, Igwo-Ezikpe MN, Okpuzor J, et al. (2011) Physico-chemical and antioxidant properties of Moringa oleifera seed oil. Pakistan J Nutr 10: 409-414.

164. Ali A, Akhtar N, Khan MS, Rasoo F, Iqbal FM, et al. (2013) Moisturizing effect of cream containing Moringa oleifera (sohajana) leaf extract by biophysical techniques: in vivo evaluation. $J$ Med Plants Res 7: 386-391.

165. Ojiako EN, Okeke CC (2013) Determination of antioxidant of Moringa oleifera seed oil and its use in the production of a body cream. Asian J Plant Sci Res 3: 1-4.

166. Kale S, Megha G (2011) Formulation and in vitro evaluation for sun protection factor of Moringa oleifera Lam (family moringaceae) oil sunscreen cream. Int J Pharm Pharm Sci 3: 371-375.

167. Warra AA (2014). A review of Moringa oleofera Lam seed oil prospects in personal care formulations. Res Rev J Pharm Nanotechnol 2: 31-34.

168. Hossain MM (2011) Therapeutic orchids: traditional uses and recent advances--an overview. Fitoterapia 82: 102-140. [Crossref]

169. Bulpitt CJ, Li Y, Bulpitt PF, Wang J (2007) The use of orchids in Chinese medicine $J R$ Soc Med 100: 558-563. [Crossref]

170. Menon S, Nayeem N (2013) Vanilla planifolia: a review of a plant commonly used as flavouring agent. Int J Pharm Sci Rev Res 20: 225-228.

171. Paul P, Chowdhury A, Nath D, Bhattacharjee MK (2013) Antimicrobial efficacy of orchid extracts as potential inhibitors of antibiotic resistant strains of Escherichia coli. Asian J Pharm Clin Res 6: 108-111.

172. Hadi H, Razali SN, Awadh AI (2015) A comprehensive review of the cosmeceutical benefits of Vanda species (Orchidaceae). Nat Prod Commun 10: 1483-1488. [Crossref] 
173. Minh TN, Khang DT, Tuyen PT, Minh LT, Anh LH, et al. (2016) Phenolic compounds and antioxidant activity of Phalaenopsis orchid hybrids. Antioxidants 5: 1-10.

174. Ribeiro AS, Estanqueiro M, Oliveira MB, Lobo JMS (2015) Main benefits and applicability of plant extracts in skin care products. Cosmetics 2: 48-65.

175. Sadler JJ, Smith JM, Zettler LW, Alborn HT, Richardson LW (2011) Fragrance composition of Dendrophylax lindenii (Orchidaceae) using a novel technique applied in situ. Eur J Environ Sci 1: 137-141.

176. Lukhoba CW, Simmonds MS, Paton AJ (2006) Plectranthus: a review of ethnobotanical uses. J Ethnopharmacol 103: 1-24. [Crossref]

177. Roshan P, Naveen M, Manjul PS, Gulzar A, Anita S, et al. (2010) Plectranthus amboinicus (Lour) Spreng: an overview. Pharm Res 4: 1-15.

178. Chifundera K (2001) Contribution to the inventory of medicinal plants from the Bushi area, South Kivu Province, Democratic Republic of Congo. Fitoterapia 72: 351-368.

179. Harsha VH, Hebbar SS, Shripathi V, Hegde GR (2003) Ethnomedicobotany of Uttara Kannada District in Karnataka, India--plants in treatment of skin diseases. $J$ Ethnopharmacol 84: 37-40. [Crossref]

180. Rabe T, van Staden J (1998) Screening of Plectranthus species for antibacterial activity. S Afr J Bot 64: 62-65.

181. Bhatt P, Negi PS (2012) Antioxidant and antibacterial activities in the leaf extracts of Indian borage (Plectranthus ambionicus). Food Nutr Sci 3: 146-152.

182. Erny SMN, Razali M, Mirfat AHS, Mohd SMA (2014) Antimicrobial activity and bioactive evaluation of Plectranthus amboinicus essential oil. Am J Res Comm 2 : $121-127$

183. Oladeji O, Adelowo F, Odelade K, Aremu S, Adisa M (2016) Senna alata: phytochemical components, characterization and medicinal benefits. CIBTech $J$ Pharm Sci 5: 40-51.

184. Adelowo F, Oladeji O (2017) An overview of the phytochemical analysis of bioactive compounds in Senna alata. Am J Chem Biochem Eng 2: 7-14.

185. Sule WF, Okonko IO, Omo-Ogun S, Nwanze JC, Ojezele MO, et al. (2011) Phytochemical properties and in vitro antifungal activity of Senna alata Linn. crude stem bark extract. J Med Plants Res 5: 176-183.

186. Ehiowemwenguan G, Inetianbor JE, Yakubu JM (2014) Antimicrobial qualities of Senna alata. IOSR J Pharm Biol Sci 9: 47-52.

187. Moriyama H, Iizuka T, Nagai M, Miyataka H, Satoh T (2003) Anti-inflammatory activity of heat-treated Cassia alata leaf extract and its flavonoid glycoside. Yakugaku Zasshi 123: 607-611.

188. Oresajo C, Yatskayer M, Galdi A, Foltis P, Pillai S (2010) Complementary effects of antioxidants and sunscreens in reducing UV-induced skin damage as demonstrated by skin biomarker expression. J Cosmet Laser Ther 12:157-162.

189. Meenupriya J, Vinisha AS, Priya P (2014) Cassia alata and Cassia auriculata Review of their bioactive potential. World J Pharm Sci 2: 1760-1769.
190. Havinga RM, Hartl A, Putscher J, Prehsler S, Buchmann C, et al. (2010) Tamarindus indica L. (Fabaceae): patterns of use in traditional African medicine. $J$ Ethnopharmacol 127: 573-588. [Crossref]

191. Al-Fatimi M, Wurster M, Schroder G, Lindequist U (2007) Antioxidant, antimicrobia and cytotoxic activities of selected medicinal plants from Yemen. J Ethnopharmacol 111: 657-666.

192. Escalona-Arranz JC, Péres-Roses R, Urdaneta-Laffita I, Camacho-Pozo MI, Rodriguez-Amado J, et al. (2010) Antimicrobial activity of extracts from Tamarindus indica L. leaves. Pharmacogn Mag 6: 242-247.

193. Mesfin A, Giday M, Animut A, Teklehaymanot T (2012) Ethnobotanical study of antimalarial plants in Shinile District, Somali Region, Ethiopia, and in vivo valuation of selected ones against Plasmodium berghei. J Ethnopharmacol 139: 221-227.

194. Luzia DMM, Jorge N (2011) Antioxidant activity, fatty acid profile and tocopherols of Tamarindus indica L. seeds. Ciênc Tecnol Aliment 31: 497-501.

195. Attah MO, Ishaya HB, Chiroma MS, Amaza DS, Balogun SU, et al. (2015) Effect of Tamarindus indica (Linn) on the rate of wound healing in adult rabbits. IOSR J Dent Med Sci 14: 80-84.

196. Naik TI, Shrikanth P, Mundugaru R, Bairy ST (2017) Wound healing activity of Tamarindus indica Linn. seed and cork ash Ayu Med Sci 2: 129-135.

197. Strickland FM, Kuchel JM, Halliday GM (2004) Natural products as aids for protecting the skin's immune system against UV damage. Cutis 74: 24-28. [Crossref]

198. Kuru P (2014) Tamarindus indica and its health related effects. Asian Pac J Trop Biomed 4: 676-681.

199. De Filipps RA, Maina SL, Crepin J (2004) Medicinal plants of the Guianas Department of Botany, National Museum of Natural History, Smithsonian Museum, Washington DC (USA)

200. May AF (1982) Surinamese folk medicine. A collection of Surinamese medicinal herbs. De Walburg Pers, Amsterdam (The Netherlands).

201. Valadeau C, Castillo JA, Sauvain M, Lores AF, Bourdy G (2010) The rainbow hurt my skin: medicinal concepts and plants uses among the Yanesha (Amuesha), an Amazonian Peruvian ethnic group. J Ethnopharmacol 127: 175-192. [Crossref]

202. Caballero-George C, Gupta MP (2011) A quarter century of pharmacognostic research on Panamanian flora: a review. Planta Med 77: 1189-1202. [Crossref]

203. Sedoc NO (1992) Afro-Surinamese natural remedies: over two hundred commonly used medicinal herbs. Vaco Press, Paramaribo (Suriname).

204. Venugopalan A, Giridhar P, Ravishankar GA (2011) Food, ethanobotanical and diversified applications of Bixa orellana L.: a scope for its improvement through biotechnological mediation. Ind J Fund Appl Life Sci 1: 9-31.

205. Funasaki M, Barroso HS, Fernandes VLA, Menezes IS (2016) Amazon rainforest cosmetics: chemical approach for quality control. Quim Nova 39: 194-209.

206. Pereira RF, Bártolo PJ (2016) Traditional therapies for skin wound healing. $A d v$ Wound Care (New Rochelle) 5: 208-229. [Crossref]

Copyright: $\odot 2017$ Mans DRA. This is an open-access article distributed under the terms of the Creative Commons Attribution License, which permits unrestricted use, distribution, and reproduction in any medium, provided the original author and source are credited. 